\title{
المقاوهة المسلحة في ظل قواعد القانون الدولي
}

\author{
shel \\ دارشيد حمد العنزي \\ أستاذ مساعد بقسم القانون الدولى_حقوق الكويت \\ د / عبدالسلام حسين العنزي \\ مدرس بقسم القانون الدولى - حقوق الكويت
}




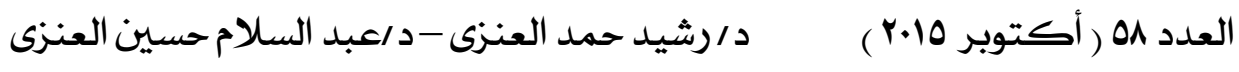

مجلت البحوث القانونيت والإقتصاديت ب ب 


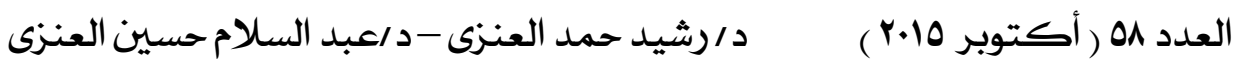

المقدهة

تعد المقاومة المسلحة من أبرز ظواهر المقاومة ضد المحتل ، والمقاومة

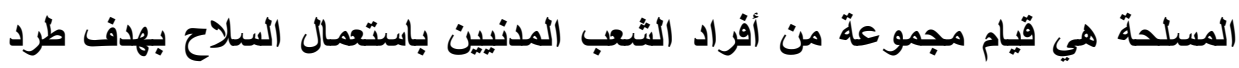

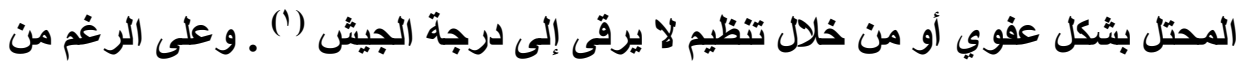

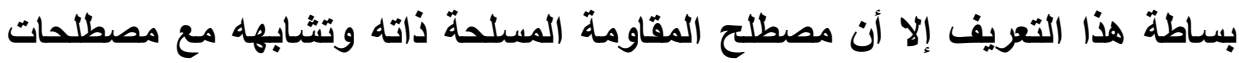

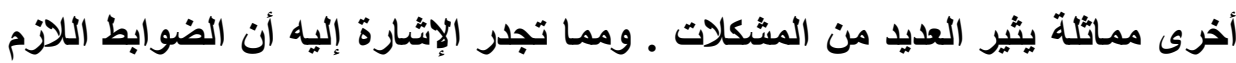
توافرها حتى يمكن تطبيق القانون الدولي الإنساني على أفراد المقاومة المسلحة

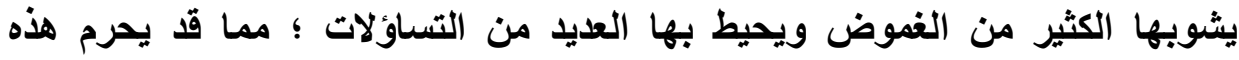
الجماعات من معاملتهم معاملة أسرى حرب لا مجرمي حرب مجردين من أي حقوق تذكر ـ يضاف إلى ذلك أن انطلاق المقاومة المسلحة من خارج إقليم الدولة المحتلة يعدّ

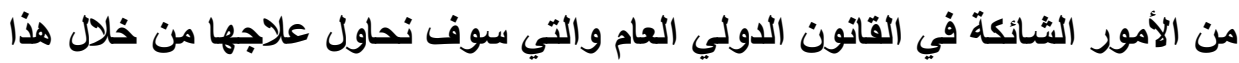

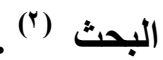

وعليه فستكون خطة دراسة (المقاومة المسلحة) في مبحثين وفقا لما يأتي : المبحث الأول : مفهوم المقاومة المسلحة . المبحث الثاني : مشروعية استعمال القوة من قبل أفراد المقاومة المسلحة

Patrick Dailler, Alain Pellet, Droit Internationl Public, 7 edition, L.D.G, P.953.

(") انظر د. احد ابو الوفا ، الوسيط في القانون الدولي العام ، الطبعة الرابعة ، دار النهضة العربية ،

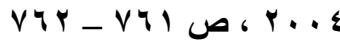

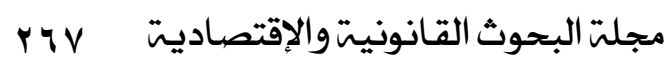




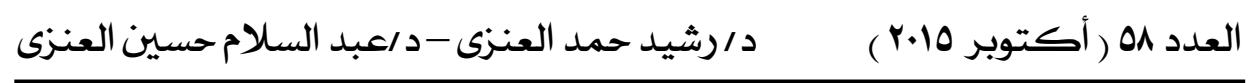

\section{المبحث الأول}

\section{هفهوم المقاوهة المسلحة}

ظهرت المقاومة المسلحة في الباية بمفهوم ضيق خلال مؤتمرات بروكسل عام

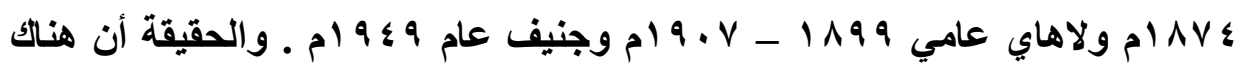

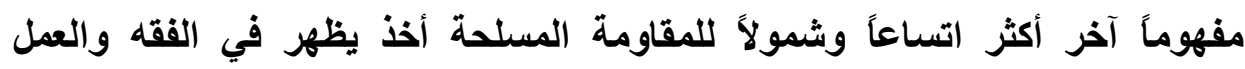

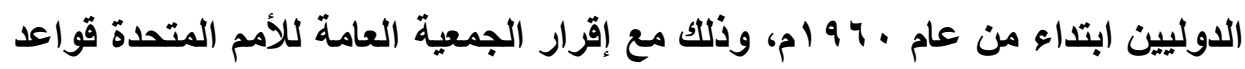

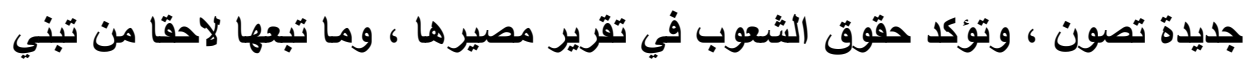

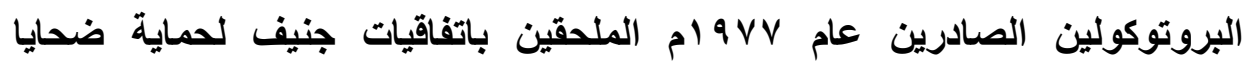

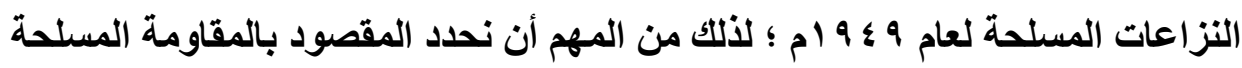

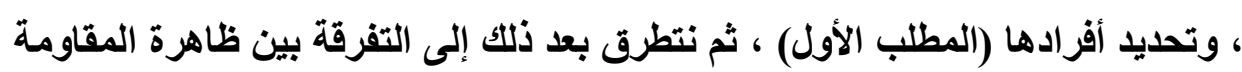
المسلحة ، وبعض الظواهر المشابهة لها (المطلب الثاني) .

\section{المطاب الأول}

\section{المقصود بالمقاوهة المسلحة}

إن المقاومة الثعبية المسلحة قد بدأت معالجتها في فقه قانون الحرب في

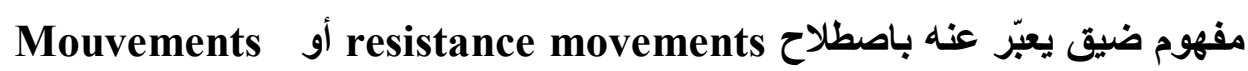

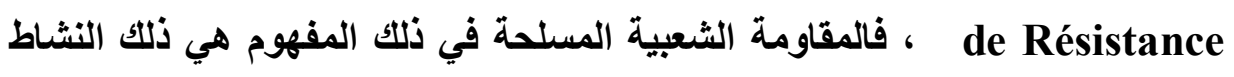

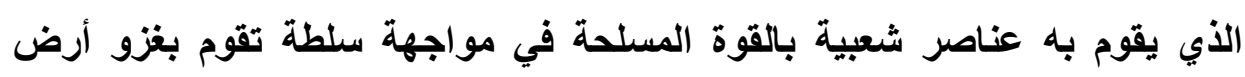




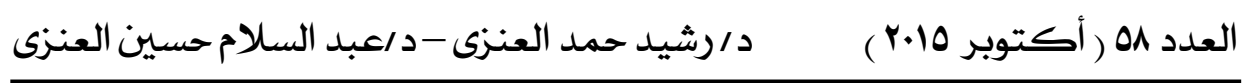

الوطن، وقد ظهر هذا المفهوم الضيق خلال مؤتمرات بروكسل عام \&V ا ام ولاهاي

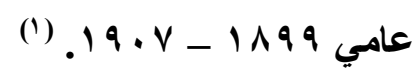

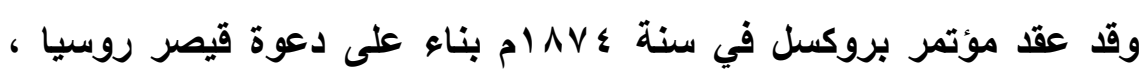
وقدمت الحكومة الروسية في ذلك المؤتمر مشروع اتفاقية دولية تتعلق بقوانين وأعراف الحرب () وتضمّن هذا المشروع الوضع القانوني للمقاومة الثعبية المسلحة، حيث نص أن حقوق المحاربين لا تكون قاصرة فقط على الجيش ، ولكنها تمتد أيضا إلى المليشيات وفرق المتطوعين في الحالات الآتية : 1- إذا كان على رأسهم مسؤول عن تابعية. r - إذا كاتت لهم علامة مميزة خارجية . r- إذا حملوا السلاح علانية. ــ إذا احترموا قوانين الحرب وعاداته. (")

ونصت المادة (YT) من هذا المشروع على أنه" يكون لأفراد المقاومة المسلحة الحق في الحصول على معاملة أسرى الحرب"، ومن ناحية أخرى نصت المادة (0 ؛ ) من ذات المشروع على أن " المواطنين في موضع لم يحتّل بعد من جانب العدو الذين يحملون السلاح للافاع عن أرض الوطن - يجب النظر إليهم على أنهم طرف محت محارب يعاملون معاملة أسرى الحرب إذا وقعوا في الأسر ".

(1) Meyrowitz Henri, la Guerilla et le droit de la guerre, problemes principaux, revue Belge de droit international, 1971, pp.56.

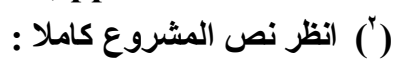

Actes de la-conférence de Bruxelles, 1874, Bruxelles imfremerie du monitor Belge, 1874.

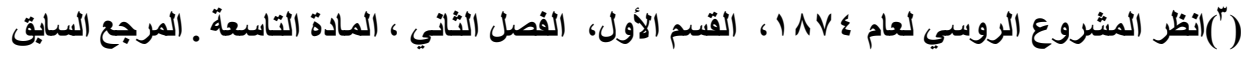

مجلت البحوث القانونيت والإقتصاديت 


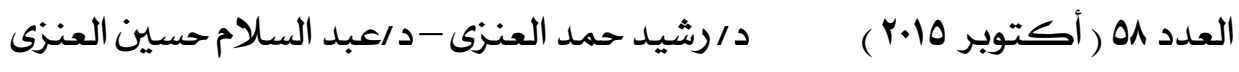

إنّ نصوص هذا المشروع المتعلق بالوضع القاتوني للمقاومة المسلحة قد حظيت بمناقشات مستفيضة على نحو لم يسبق له مثيل ، حيث رفضت العديد من الحكومات تلك القواعد المتعلقة بالمقاومة المسلحة، وعلى ذلك لم يتم التصديق على مشروع بروكسل ، ولكن بقى لهذا المشروع قيمة فقهية كبيرة ، كما أنه كان أساسا لأعمال مؤتمري لاهاي

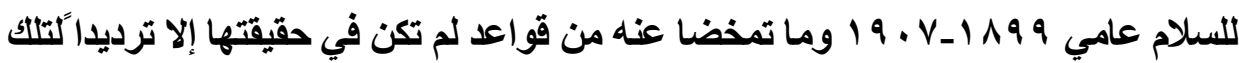
القواعد التي تم إرساؤها في مشروع بروكسل ، ومع بقاء هذا المشروع دون تصديق

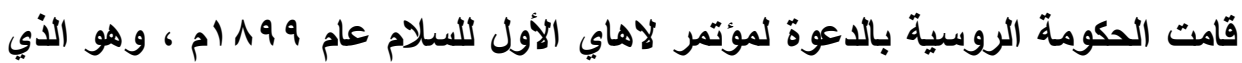

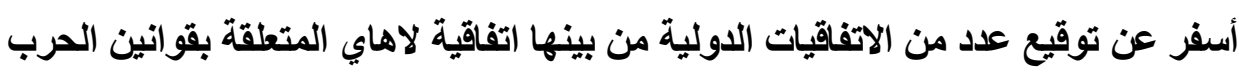
البرية وأعرافها (') التي تم التأكيد فيها على حق المقاومة الثعبية ، فقد نصت المادتان الأولى والثانية منها على جواز إضفاء وصف المقاتل على المواطنين الذين يشاركون في المقاومة وبخاصة المواطنون الذين يقومون بالمقاومة في إقليم غير محتل بشرط احترام قوانين الحرب وأعرافها. وفي عام V • 9 ام عقد مؤتمر لاهاي الثاني الأي أسفر عن عقد العديد من الاتفاقيات الدولية حيث حلت اتفاقية لاهاي المتعلقة بقوانين الحرب البرية

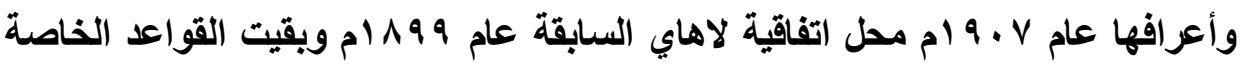
بالمقاومة الثعبية المسلحة كما وردت في المادتين الأولى والثانية كما هي في اتفاقية لاهاي لعام V • 9 ام ، ومما يجدر ذكره أنّ هناك العديد من النصوص في اتفاقية لاهاي

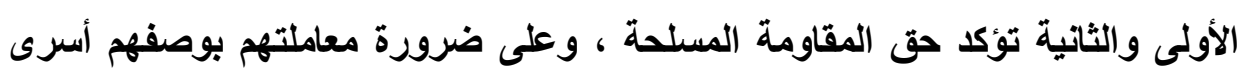
حرب.

(1) Scelle Georges, la conference de Bruxelles de 1874, librairie de la societe de Recueit. J.B.sirey et du journal du palais, paris, 1906, p.20. 


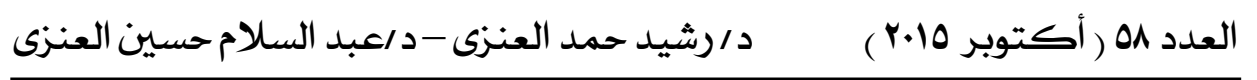

تميـزت الفتـرة التــي صــاحبت الحـرب العالميـة الثانيـة باتتـشـار حركــات

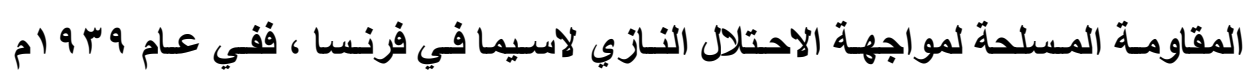
نصّّ أحكام محكمة لاهاي على انسه لا يتمتع بصفة المحارب إلا من ينتمي إلى حركة مقاومة منظمة، أما حركات المقاومة العقوية فلا تتمتع بأية حقوق ، واستغلت ألمانيا

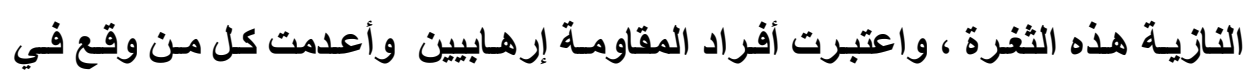

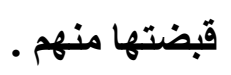

ومن الآثار المباشرة للحرب العالميـة الثانيـة بعد انتهائهـا عقد مؤتمر جنيف الابلوماسي، بناءاً على دعوة مجلس الاتحاد السويسري بمدينة جنيف في القترة بين

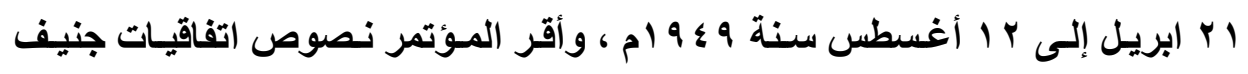
لحمايـة ضـحايا النزاعـات المسلحة التي أصبحت بحق حجر الأسـاس للقـانون الـدلي الإنساني، وهذه الاتفاقيات هي: ا. اتفاقية جنيف لتحسين أحوال الجرحى والمرضى من القوات المسلحة في الميدان

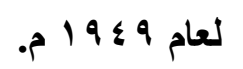
r. اتفاقية جنيف لتحسين أحوال الجرحى والمرضى والغرقى بالقوات المسلحة في

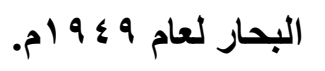
r. اتفاقية جنيف الخاصة بمعاملة أسرى الحرب لعام 9 ؟ 9 م. ؛. اتفاقية جنيف الخاصة بحماية الأشخاص المدنيين وقت الحرب لعام 9 ؛ 9 ام. 


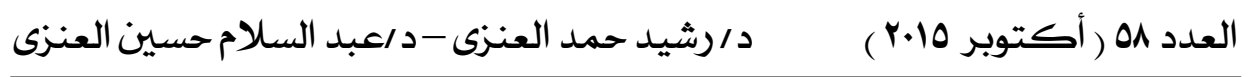

كانـت مسشكلة الوضـع القـانوني لأفر اد المقاومـة مسن أصسب المسشكلات التـي

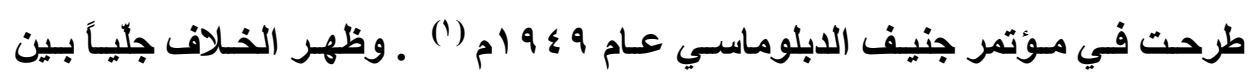

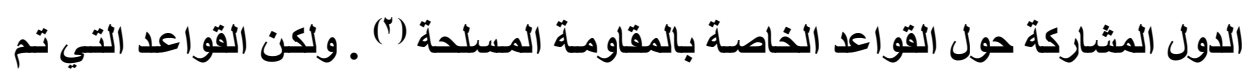

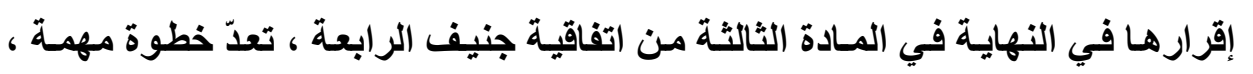

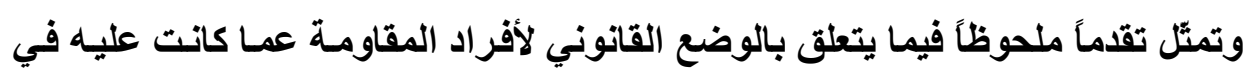
السابق.

فقد حددت المادة الرابعة من اتفاقية جنيف الثالثة أسرى الحرب وشملت أفراد المقاومة المسلحة حين نصت على أن أفراد الميليثيات الأخرى ، والوحدات المتطوعة

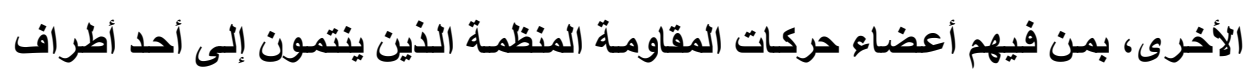
النزاع ، ويعملون داخل أو خارج إقليمهم يعدّون أسرى حرب بشرط توافر الشروط

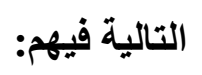

اـ أن يقودها شخص مسؤول عن مرؤوسيه: من الواجب أن يكون أفراد المقاومة

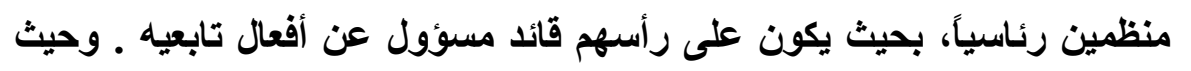

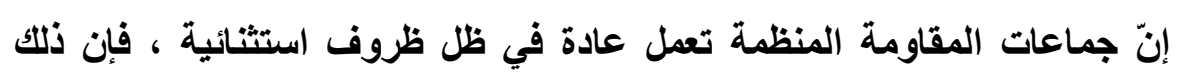
يستلزم بالضرورة وجود شخص معين يتولى القيادة (") .

(1) Kunz, Josef, L., "The Geneva Conventions of August 12, 1949, (In Law and Politics in the world community), P. 314. Draper, G.I.A, The Geneva Conventions of 1949, Recueil des cours de l' Academie de Droit International de la Haye, 1965.

(2) Draper, G.I.A, "The Legal classification of belligerents individuals (Humanitarian Law and armed conflicts), Centre de Droit International de l'University de Bruxelles Institute de Socioligie, 1971.

(3) Fauchille, Paul, Traite de droit International Public, Tome II, Guerre et Neutralite, Paris, 1921, p. 10.

rvr مجلت البحوث القانونيت والإقتصاديت 
r- أن تكون لها شارة مميزة محددة يمكن تمييزها عن بعد: أن العلامة المميزة لا

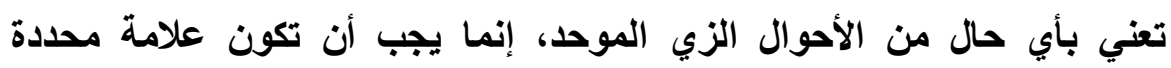

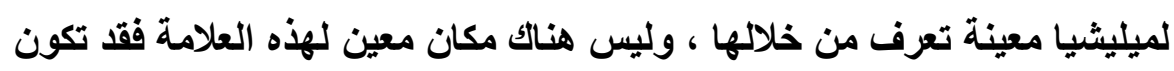

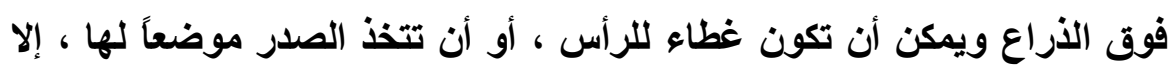

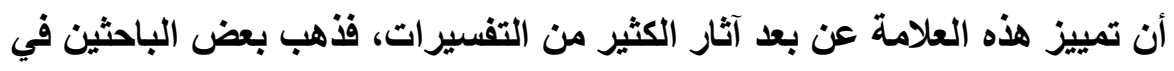

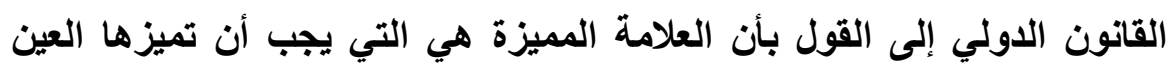

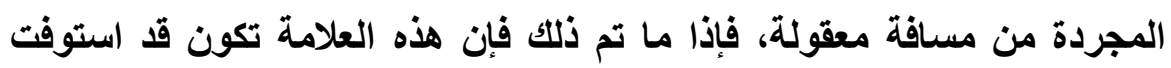

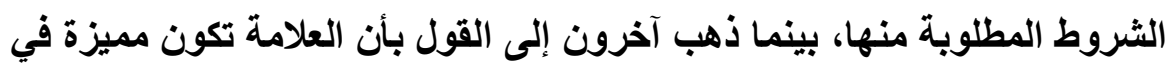

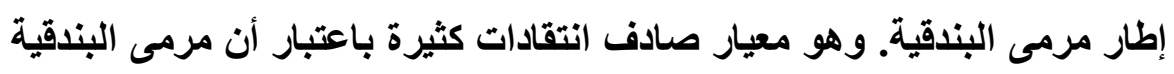

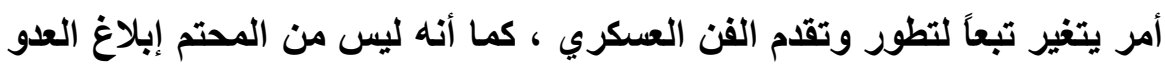

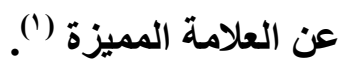

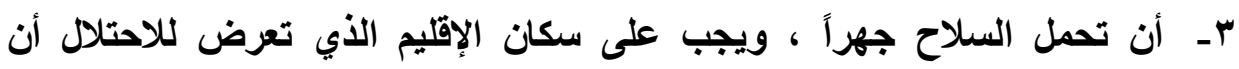

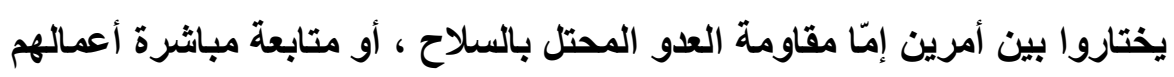

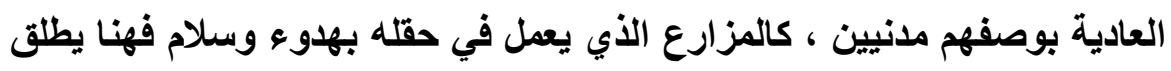
عليه وصف المدني ، ويتمتع بحماية اتفاقية جنيف الرابعة الخاصة بالمدنيين لعام

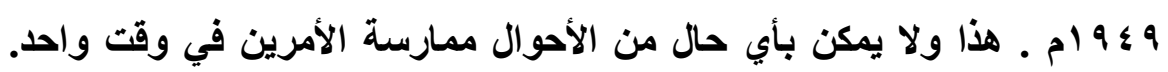

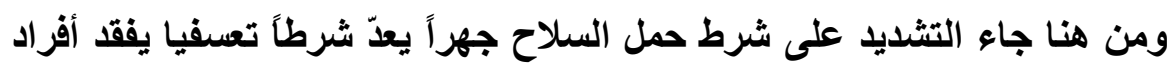

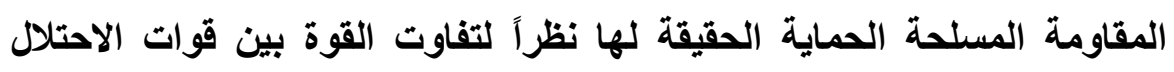
وأفراد المقاومة المسلحة . 
العدد هo ( أكتوبر 10.r. ) د/رشيد حمد العنزى -د اعبد السلام حسين العنزى

צ- أن تحترم قو انين الحرب وعادتها فإِّهه من الضروري أن تحترم المقاومة المسلحة المنظمة قوانين وأعراف الحرب، باعتبار أن ذلك مطلب تدعو إليه الإنسانية

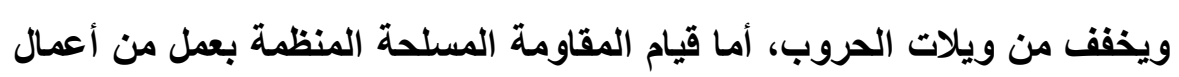

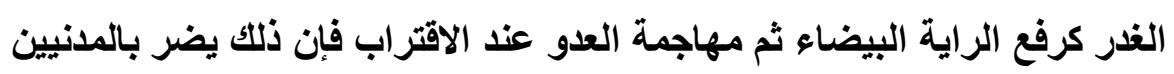

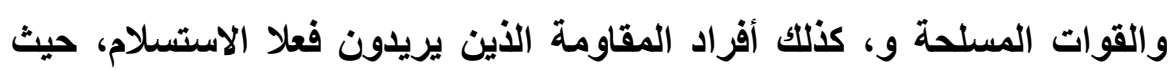

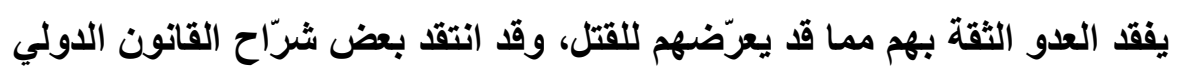

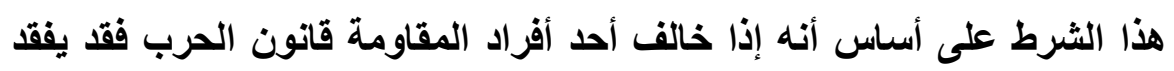

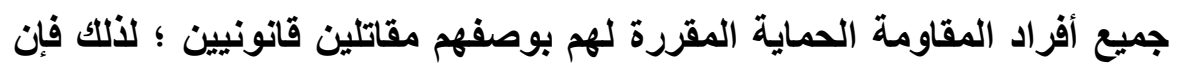

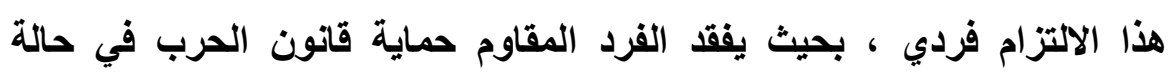

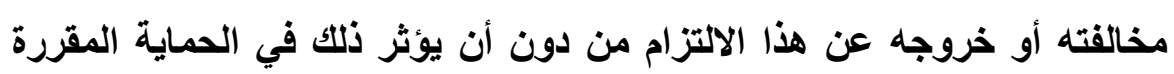

$$
\text { لجماعة المقاومة التي ينتمي إليها. }
$$

هذا ويجب التتويه بأن اتفاقية جنيف الثالثة قد أضفت صفة الأسير على أفراد

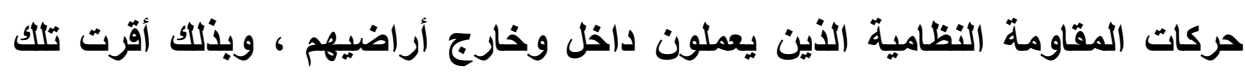

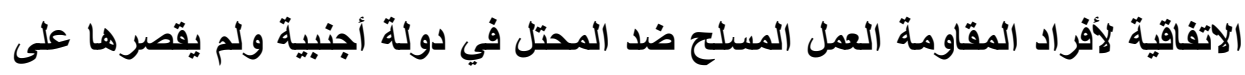

$$
\text { العمل داخل إقليم الدولة ('). }
$$

وقد ثار خلاف كبير في كيفية تمييز أفراد المقاومة المسلحة عن بقية السكان

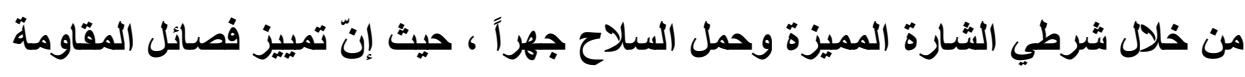

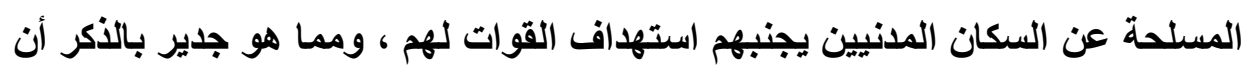

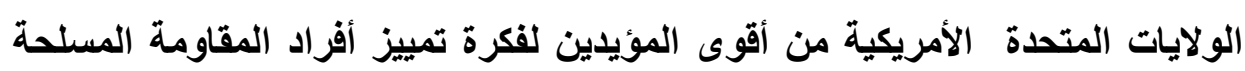

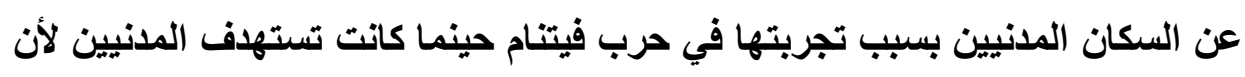

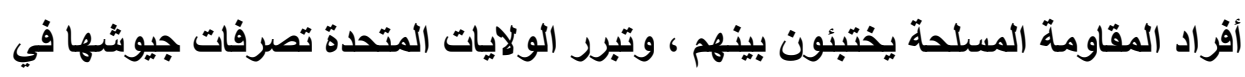

(') انظر اتفاقية جنيف الثالثة الخاصة بحماية أسرى الحرب المادة (؟)، فقرة (ץ) PV ع مجلة البحوث القانونيت والإقتصاديت 


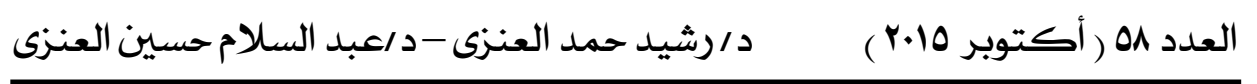

فيتنام استناداً إلى أن عدم تمييز أفراد المقاومة المسلحة الفيتناميين عن باقي أفراد السكان المدنيين يجعل من هؤلاء المدنيين جزءاً من أفراد المقاومة المسلحة وذلك آلك لتبرير عدوانها على القرى الفيتنامية آنذاك .

لكن معيار تمييز أفراد المقاومة الثعبية المسلحة عن السكان المدنيين غير واضح ، حيث يرى بعض الباحثين في القانون الدولي ضرورة أن يرتدي أفراد المقاومة المسلحة زياً عسكرياً خاصاً بهر ، ويمكن القول أن الزي العسكري ليس شرطاً لتمييز أفراد المقاومة الشعبية ، فالمادة الرابعة من اتفاقية جنيف الثالثة تعود في أصلها التاريخي إلى اتفاقية لاهاي الرابعة لسنة V • 19 بشأن قوانين الحرب البرية وأعرافها التي لم تحدد الثروط الواجب توافرها في "القوات المسلحة" حتى يمكن اعتبارها كذلك (1) لكنها تكلمت فقط عن الشروط الواجب توافرها في الميليشيات والقوات المتطوعة والتي ليس من ضمنها شرط الزي المميز ، ومن ثم فإذا كان شرط الزي المميز لا يؤخذ به فيما يتعلق بالميليشيات المسلحة الملحقة بالقوات المسلحة والتي تأخذ حكم القوات المسلحة النظامية فإنه بالتأكيد ليس شرطاً في أفراد المقاومة المسلحة الذين يخضعون لمعايير أقل صرامة من تلك التي تتميز بها القوات المسلحة والميليشيات الملحقة بها ، كذلك فإن فكرة ارتداء أفراد المقاومة المسلحة زياً عسكرياً خاصاً يجعلهم معروفين ومميزين مما قد يجعل اصطياد هم أمرا سهلا . بالإضافة إلى الفقرة (ب) من المادة الرابعة سالفة الذكر أوردت اتفاقية جنيف الثالثة في المادة الرابعة في الفقرة (ج) منها حالة قد تأخذ حكم المقاومة المسلحة لأنها تهدف إلى مقاومة الغازي وهي حالة الهبّة الثعبية أو الجماهيرية (La Levee en) (') (') (') (لنصوص الاتفاقية (نظر

Roberts, A. and Guelff, R. (eds.), Documents on the Laws of War, 2nd ed., (Oxford, 1989), p. 43-59.

rvo مجلة البحوث القانونيت والإقتصاديت 


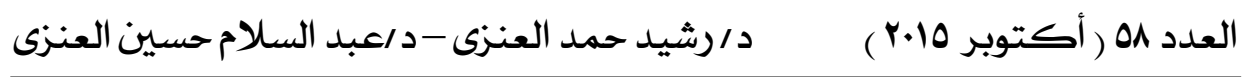

أسوأ وهولاء هم سكان الأراضي غير المحتلة الذين يحملون السلاح من تلقاء أنفسهم عند اقتراب العدو لمقاومة القوات الغازية دون أن يتوافر لهم الوقت لتثنكيل وحدات مسلحة نظامية (') ، ويتمتع أفراد الهبّة الجماهيرية بالحماية التي توافرها اتفاقية جنيف الثالثة بشأن الحرب باعتبارهم أسرى حرب إن وقعوا بيد قوات العدو

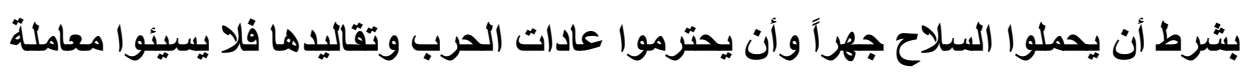
الأسرى ، أو أن يستغلوا النساء والأطفال دروعاً بشرية ، كل ذلك لعدم الإضرار ببقية

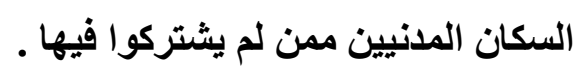

ويذهب جانب من الفقه إلى أن الأخذ بنظام التجنيد الإلزامي يفقد الهبّة

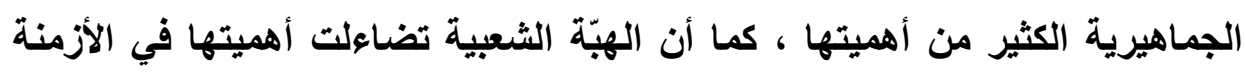
الحديثة ؛ وذلك بسبب الثورة الهائلة في فنون الحرب ووسائل تسيرها ، بحيث أصبح تصدي الشعب لمقاتلة العدو المحتل في شكل هبة شعبية أمر غير ذي جدوى بما يحمله معه من مخاطر غير محدودة بالنسبة للمدنيين، ومن ثم فإن هذا الثكل الأصيل

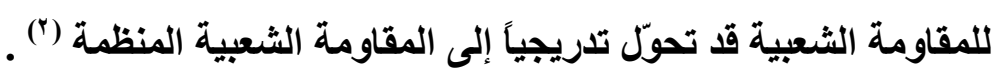
وواقع الأمر أن التقليل من أهمية الهبّة الثعبية لا يصمد للنظر العميق ؛ ذلك لأن نظام التجنيا الإلزامي لا يمكن أن يكون عوضاً عن الهيّة الشعبية التي تثارك فيها

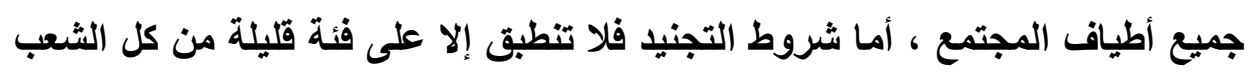
الأي يشكل الهبّة الشعبية ، كما أن الهبّة الشعبية في العصور الحديثة أثبتت فعاليتها في إيقاع خسائر فادحة في العدو المحتل ؛ مما أدى إلى تحريك الرأي العام في بلاد

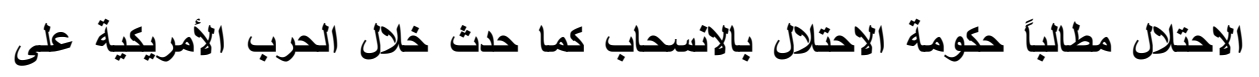

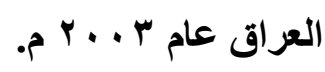

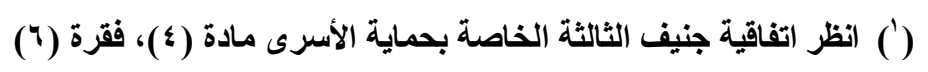
(2) Fachille Paul, Traite de Droit International Public p. 108.

rVT مجلت البحوث القانونيت والإقتصاديت 


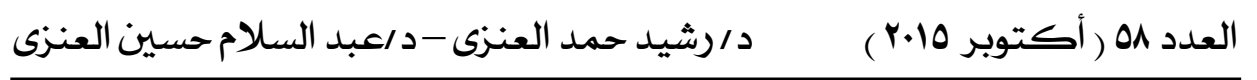

يعدّ نص المادة الرابعة من اتفاقية جنيف الثالثة تتويجاً لحق الثعوب في مقاومة المعتدي ، وعلى وجه الخصوص مقاومة قوات الاحتلال ، إلا أن بعض الشراح يعدّه انتصاراً لوجهة نظر الدول الاستعمارية التي لم تعرف الخضوع للاحتلال الأجنبي ،

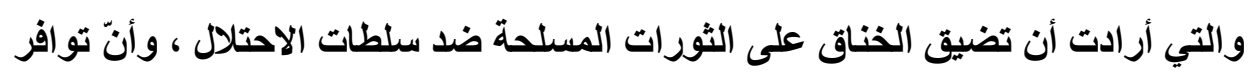
الشروط الأربعة المذكورة أعلاه للاعتراف بصفة المقاومة المنظمة فيه إضعاف لحركة المقاومة ، وتقليل من تأثيرها في ظل عسف الاحتلال ومواجهة قواته (') ـ ففي ظل احتلال كلي لإقليم الدولة لا يمكن أن تقوم مقاومة مسلحة منظمة بالثروط المن المذكورة أعلاه خصوصاً شرطي حمل السلاح جهراً وتمييز المقاتلين أنفسهم عن السكان المدنيين ؛ ولذلك تقوم عادة أعمال مقاومة مسلحة سرية تعتمد التخفي وسيلة لها ، نظراً لتفاوت الإمكانيات العكرية بين قوات المحتل ، وقوات المقاومة المسلحة ـ فمثلا فرد المقاومة الأي يحمل السلاح جهرا أو المقاتلين المميزين عن السكان المدنيين

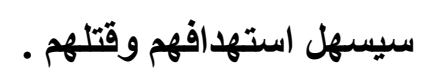
ومع ذلك يمكن فهم موقف اتفاقية جنيف الثالثة بالنظر إلى حقيقة العلاقات الدولية إبان القتال من جهة ، وتأثير تيارات دولية قوية على ظهور المادة بهذا

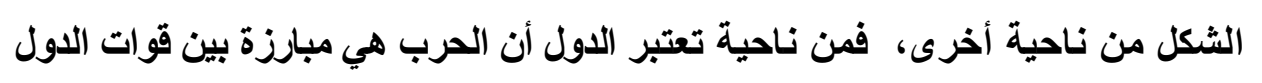

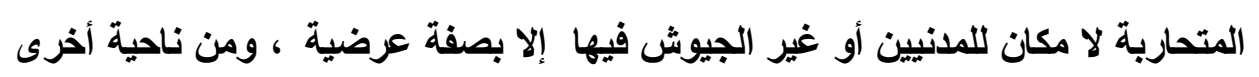
تحاول دول كثيرة الاعتراف بحركات المقاومة المسلحة نظراً لخطورة "حرب العصابات" لإنه

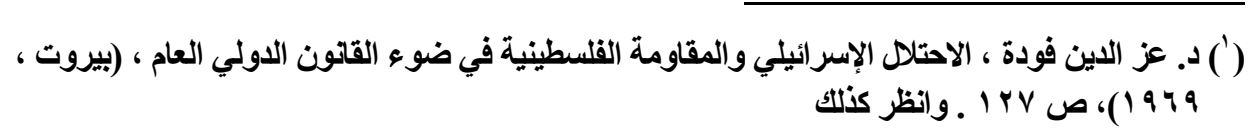
Aldrich, George, "Guerrilla Combatants and Prisoners of War Status", The American University Law Review, vol. 31, Summer 1982, No. 4, p. 871 at 872

rVV مجلة البحوث القانونيت والإقتصاديت 


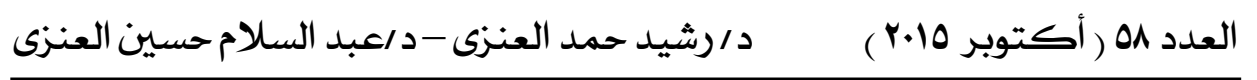

على أمن المقاتلين القاتونيين (') ، وفي الجاتب الآخر من هؤلاء يقف المؤيدون لحق الثُعوب في تقرير مصيرها وحقهم في مقاومة المحتل بثتى الوسائل المتاحة بما في ذلك

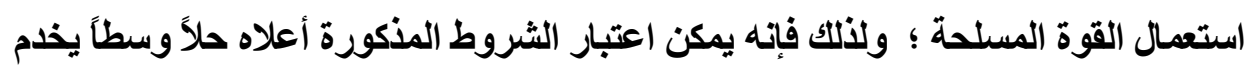
مصالح الطرفين ، فهو يخدم مصلحة دولة الاحتلال من حيث تمييز المقاتلين عن المدنيين مما يعطيها حرية كبيرة في التعامل مع أي خطر قد يحيق بقواتها، ويحمي المدنيين في ذات الوقت ، وهي تحمي في الوقت نفسه أفراد الميليشيات وحركات المقاومة المنظمة من خلال انطباث نصوص اتفاقية جنيف الثالثة عليهم ، وتمتعهم بصفة أسرى الحرب إذا ما وقعوا

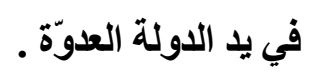

وقد انتبهت الدول بتوجيه من الصليب الأحمر إلى صعوبة تطبيق شروط المقاومة المسلحة وبالذات شرْطيْ العلامة المميزة ، وحمل السلاح جهراً في اتفاقية

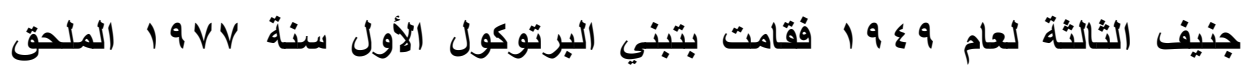
باتفاقيات جنيف لسنة 9 9 19 الذي خفف من تلك الثروط بطريقة أكثر ملاعمة

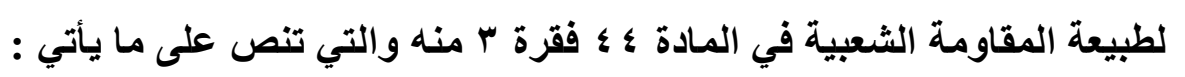
"يلتزم المقاتلون، إزكاء لحماية المدنيين ضد آثار الأعمال العدائية، أن يميزوا أنفسهم عن السكان المدنيين أثناء اشتباكهم في هجوم أو في عملية عسكرية تجهز للهجوم. أما وهناك من مواقف المنازعات المسلحة ما لا يملك فيها المقاتل المسلح أن يميز نفسه على النحو المرغوب، فإنه يبقى عندئذ محتفظاً بوضعه كمقاتل شريطة أن يحمل سلاحه علناً في مثل هذه المواقف :

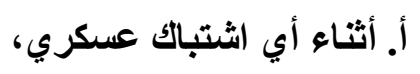

(') راجع د. حامد سلطان و د. عائشة راتب و د. صلاح الدين عامر ، القانون الدولي العام ، الطبعة الرابعة،

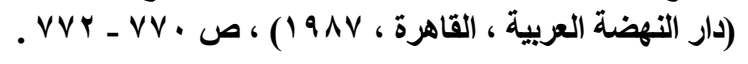

rV^ مجلت البحوث القانونيت والإقتصاديت 


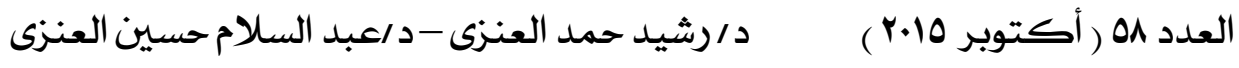

ب. طوال ذلك الوقت الأي يبقى خلاله مرئياً للخصم على مدى البصر أثناء انثغاله بتوزيع القوات في مواقعها استعداداً للقتال قبيل شن هجوم عليه أن يشارك فيه، ولا يجوز أن تعتبر الأفعال التي تطابق شروط هذه الفقرة من قبيل الغدر في معنى

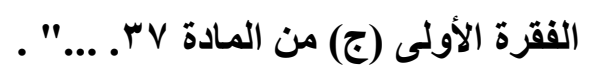

وهذان الشرطان اللأن جاءت بهما المادة ؟ ؛ فقرة ب من البروتوكول الأول

I AVV رفضتهما الولايات المتحدة الأمريكية معتبرة أن البروتوكول الأول لسنة يحتوى على نصوص لا يمكن القبول بها ، وقد تثكل خطرا على حياة الجنود الأمريكيين (1) ، ومما يؤسف له أن تبرر الحكومة الأمريكية معارضتها للبروتوكول

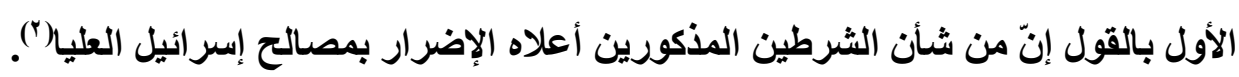

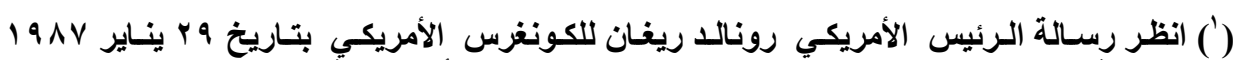

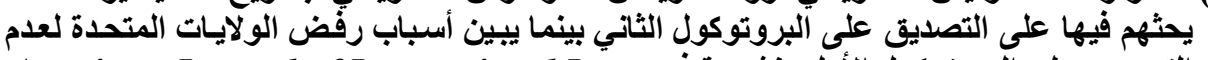

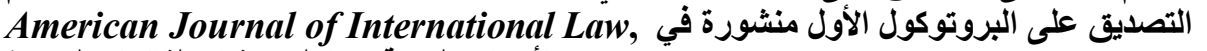

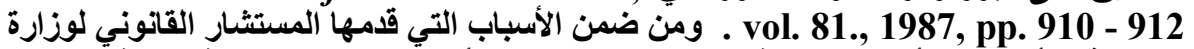

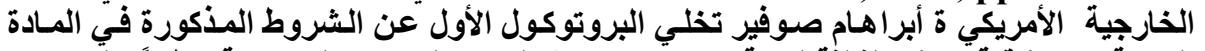

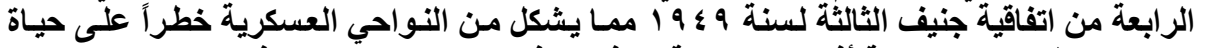

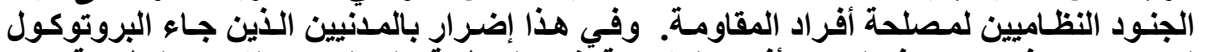

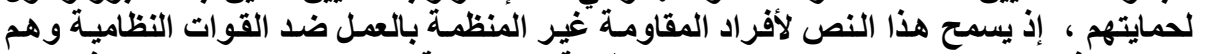

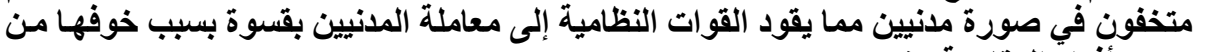

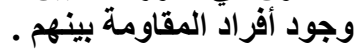

Sofaer, Abraham D., "The U.S. Decision not to Ratify Protocol 1 to the Geneva Conventions on the Protection of War Victims The Rationale for the United States Decision”, A.J.I.L, vol. 82, 1988, pp. 784 - 787

$$
\text { وانظر كذلك }
$$

Gradam, J.G., "Noncombatant Immunity and the Gulf Conflict", Virginia Journal of International Law, vol. 32, 1992, pp. 832 - 827 .

(') Abraham D. Sofaer, "The U.S. Decision not to Ratify Protocol 1 to the Geneva Conventions on the Protection of War Victims The Rationale for the United States Decision", American Journal of International Law, vol. 82, 1988, pp. 784 - 787; also Gradam, J.G., "Noncombatant Immunity and the Gulf Conflict", Virginia Journal of International Law, vol. 32, 1992, pp. $832-827$ 
العدد هo ( أكتوبر 10.r. ) د/رشيد حمد العنزى -د اعبد السلام حسين العنزى

ويتضح مما سبق أن البروتوكول الإضافي الأول لعام 19VV المتعلق بحماية

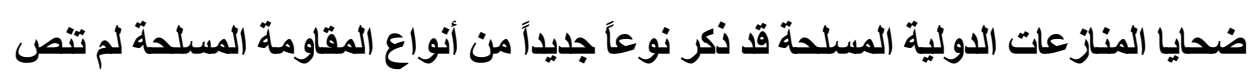

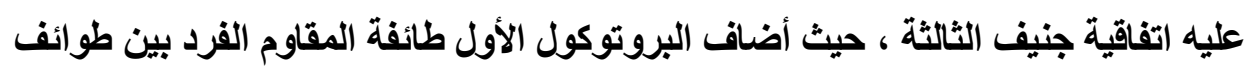
الأثخاص الذين يكون لهم الحق في الحصول على وصف أسير الحرب .

ويناء على هذا الأساس فإن القانون الاولي الإنساني يعترف للمقاوم الفرد

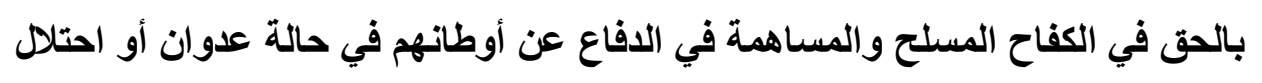

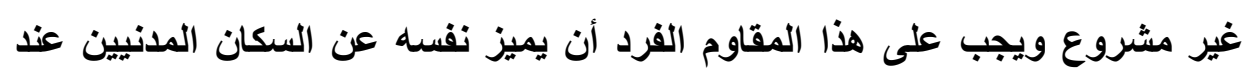

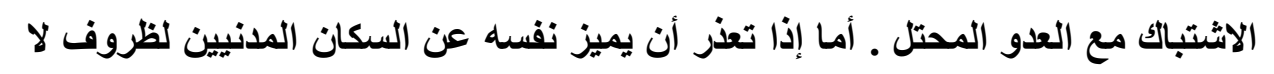

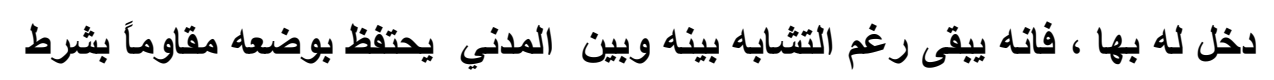

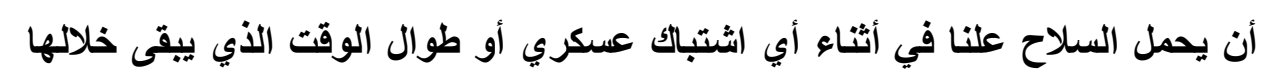

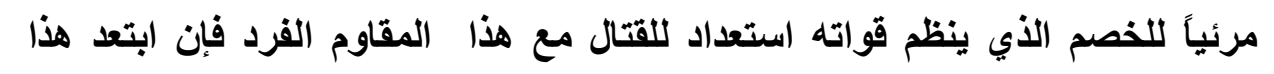

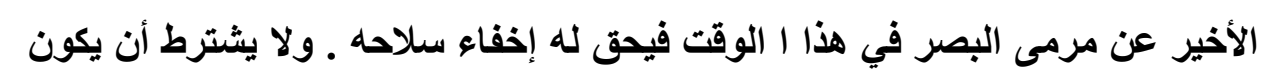

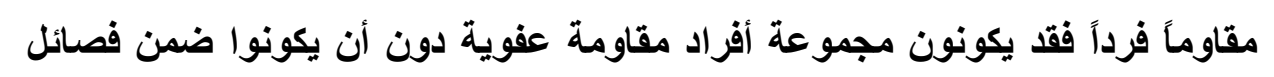

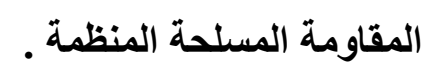
وبذلك يمكن القول بان أفراد المقاومة المسلحة هم : ا- المليثيات أو الوحدات المتطوعة التي تثكل جزعاً من القوات المسلحة. r- المليثيات أو الوحدات المتطوعة المستقلة عن القوات المسلحة .

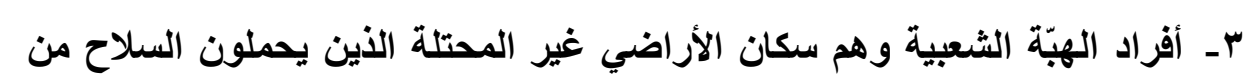

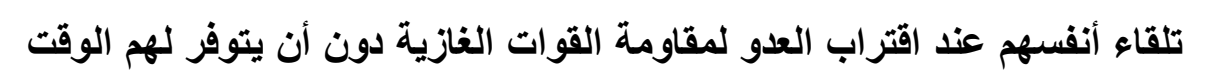
لتشكيل وحدات مسلحة نظامية .

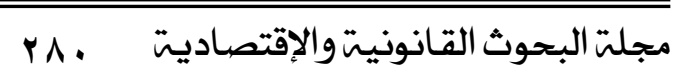




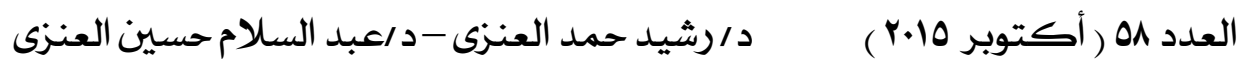

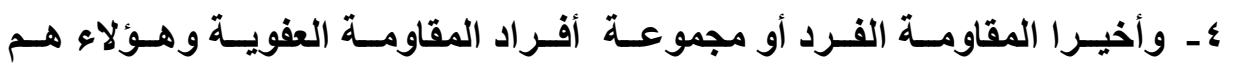

الأفراد المــنيون " مجتمعـين أو منفـردين " الـذين يقومـون بعمليـات مقاومسة

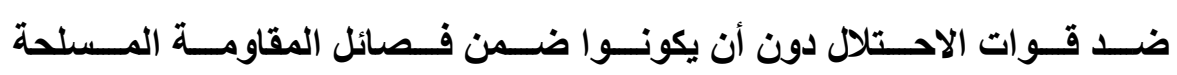

المنظمة .

ويمكن القـول بـأن التطور المـذكور أعـلاه قـد جـاء نتيجـة التطـورات الدوليـة

التي ظهرت واضحة في حقبة الستينيات من القرن الماضي حين شـهـ المجتمع الدولي

ظهور مفهوم آخر أكثر اتساعاً وشمولا للمقاومة المسلحة في الفقهـه والعمل الدوليين ،

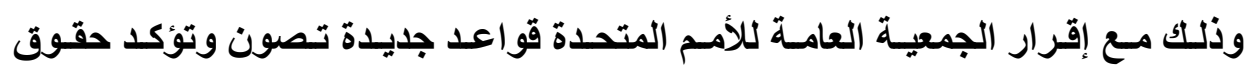
الشعوب في تقرير مصيرها ، فقد جاء إعلان منح الاستقلال للبلاد والثعوب المستعمرة الذي صـدر عن الجمعيـة العامـة للأمسم المتحدة في دورتها الخامسة عشرة بتــاريخ

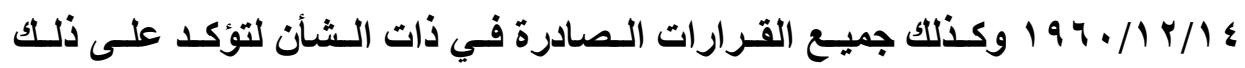

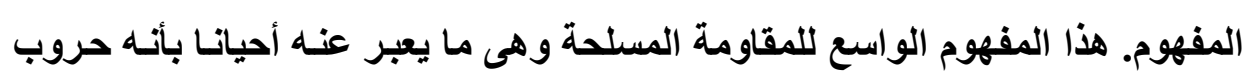
التحريـر الـوطني (wars of national liberation) يمكن أن نعرفها بأنها "عمليات القتال التي يقوم بها عناصر وطنيون من غير أفراد القوات المسلحة النظامية دفاعا عن المصالح الوطنية أو القومية ضد قوى أجنبية سواء كاتت تلك العناصر تعمل فيل فئل

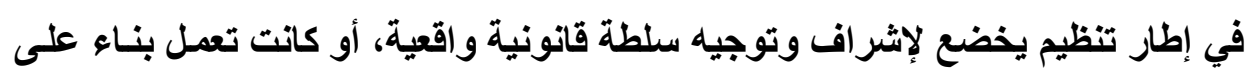
مبادرتها الخاصة ، و سواء باشرت هذا النشاط فوق إقليم الوطن أو من قواعد خـارج

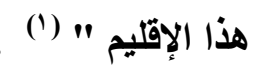

(') (انظر د. صلاح الدين عامر ، المقاومة الثعبية المسلحة ، دار الفكر العربي ، (دون سنة نشر) ،

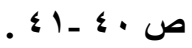

rیl مجلت البحوث القانونيت والإقتصاديت 


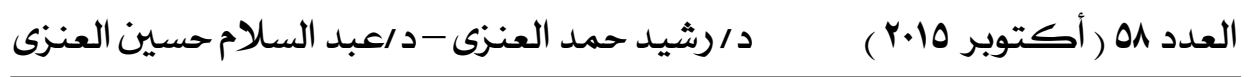

وبناء على ما ذكر أعلاه فإنها يمكن استنتاج العناصر الأساسية المميزة للمقاومة

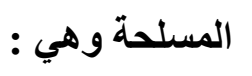

\section{ا- أنها تتضمن عمليات قتالية مسلمة :}

يعدّ استخدام القوة المسلحة أحد العناصر الرئيسية لقيام المقاومة المسلحة، والمقصود باستخدام القوة المسلحة هو مباشرة القتال ضد العدو الذي تجرى ضده

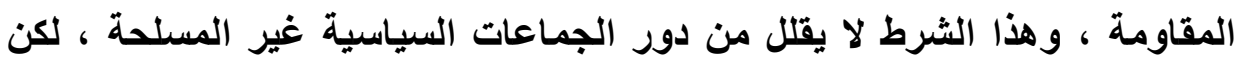
قواعد القانون الدولي الإنساني تسرى عادة عند قيام نزاع مسلح ، ومن ثم فإن من شروط المقاومة أن تكون مسلحة، ومع ذلك فإنه في ظل الاحتلال يظل رجال المقاومة السلمية معنيين بموجب قواعد القانون الدولي الإنساني بوصفهم مدنيين تحت الاحتلال ، وهؤلاء محميين بموجب اتفاقية جنيف الرابعة لعام 9 ؛ 9 ا م (") . r- إنها تقوم ضد قوات همتلة

تنشأ المقاومة المسلحة كونها ردّ فعل تلقائياً عند قيام جيش العدو باحتلال البلاد ، أو بشن حرب عدوانية عليها ، أو يحول دون حق الثعب في الاستقلال، فيقوم أفراد من الشعب بحمل السلاح تلقائيا أو في إطار معين ، ومن هنا فإن المقاومة المسلحة يجب أن تجرى دائما ضد عدو أجنبي، ومن ثم فإنه يخرج من هذا المعنى الصراع المسلح الأي يقوم بين قوات متمردة والسلطة الحاكمة حيث إنّ المقاومة المسلحة تختلف بذلك عن الحرب الأهلية التي تكون خاضعة لأحكام البروتوكول الثاني 9VV ام الملحق باتفاقيات جنيف الأربعة لعام 9 9 9 ام (r) . والمقاومة المسلحة تختلف كذلك في مفهومها عن لن

$$
\begin{aligned}
& \text { (') المرجع السابق ، ص • • . }
\end{aligned}
$$

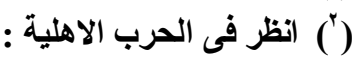

Oppenheim, L., International Law, vol.II , war and neutrality, $7^{\text {th }}$ ed., Lauterpacht, (ed.), London, 1958, p.209.

r r r مجلت البحوث القانونيت والإقتصاديت 


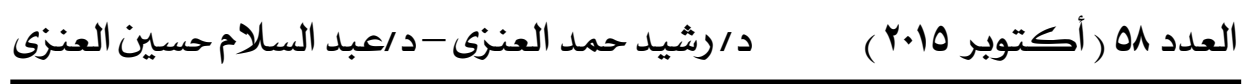

حروب الانفصال التي يقوم بها المواطنون في إقليم من الأقاليم ضد الدولة الأم للانفصال عنها وتكوين دولة جليدة. r- بقوم بهما أفراد عاديون :

ويقصد بالأفراد العـاديين أولئك الذين يقومون بالمقاومـة المسلحة خـارج إطـار الجيوش النظامية بغض النظر عن انتمـائهم للقوات المسلحة النظامية لبلادهم ؛ لذلك فإن أفراد القوات المسلحة الذين التحقوا بخدمة أمن البلاد وبموجب قانون خاص قبل احتلال البلاد ، وقاوموا بعد ذلك الاحتلال من خلال تنظيم معين أو بشكل تلقائي بعيداً عن القوات المسلحة النظامية الذين ينتمون إليها ، فإنهم يتمتعون بالحمايـة المقررة

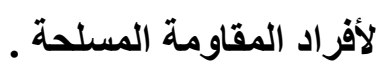

ع- الدانع الوطني : مما لا شك فيه أن أفراد المقاومة المسلحة عندما يلجؤون للسلاح فإنهم يقومون بذلك بدافع من مشاعرهم الوطنية وذلك للتصدي لأي عدوان خارجي على بلادهم أو بهذف تحريرها من الاحتلال ، كما أنه يجوز أن يشارك في المقاومة المسلحة أشخاص ممن لا يحملون جنسية الإقليم المحتل أو المعرض للعدوان مادام الدافع وراء مشاركتهم ليس المال أو المكاسب المادية الأخرى ـ كما أن الأعمال المسلحة التي يقوم بها أفراد المقاومة تختلف عن تلك العمليات الحربية التي يقوم بها مجموعة من الأفراد

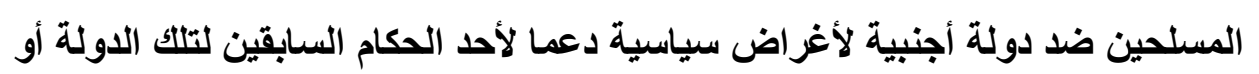

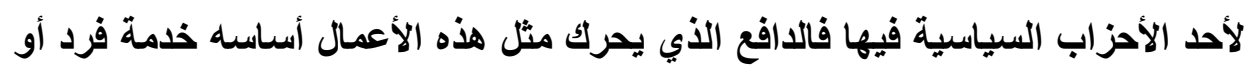
فئة ، أما الدافع الذي يحرك أفراد المقاومة المسلحة فهو المصلحة الوطنية المجردة (')

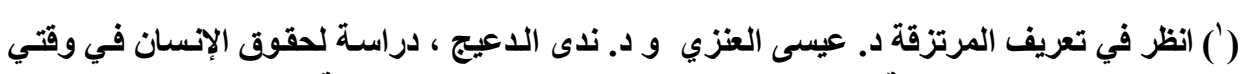

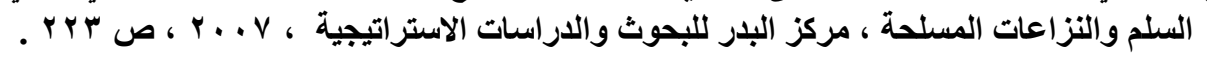

$$
\text { r r r مجلة البحوث القانونيت والإقتصاديت }
$$


د رشيد حمد العنزى - د/عبد السلام حسين العنزى

ب

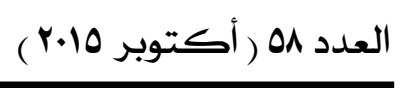

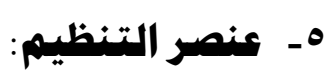

لا يشترط القانون الدولي في المقاومة المسلحة أن تكون منظمة وان كان عنصر

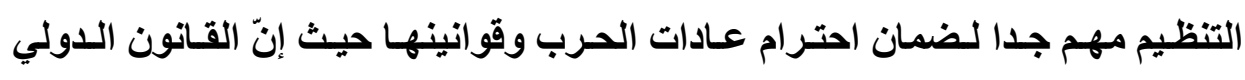

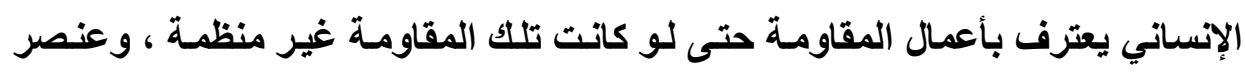

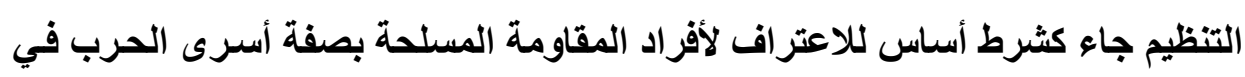

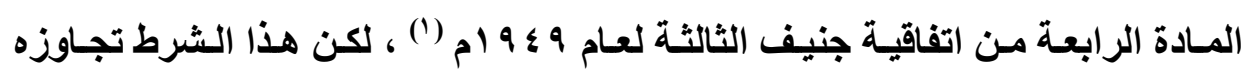

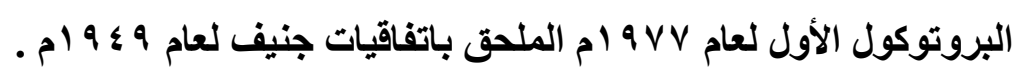

\section{المطاب الثاني}

\section{التفرقة بين ظاهرة المقاوهة المسلحة وبعض الظواهر المشابهة لها}

بييّا فيما سبق أن المقاومة المسلحة هي عمليات القتال التي يقوم بها عناصر وطنية

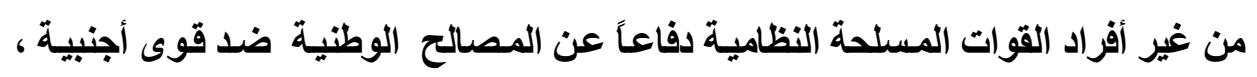

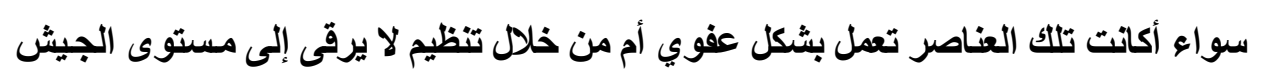

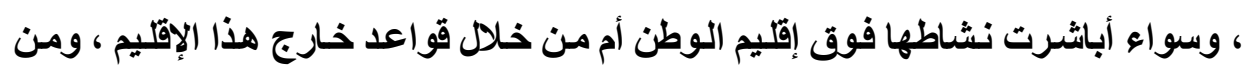

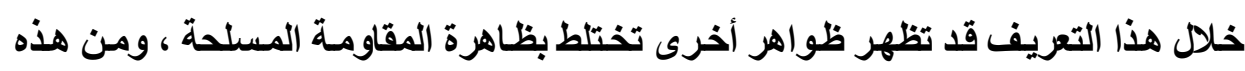

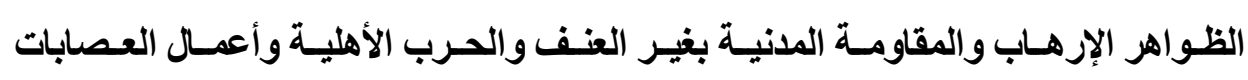

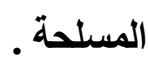

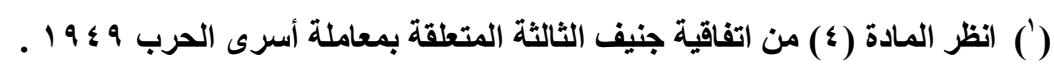

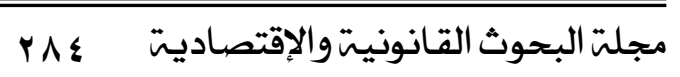




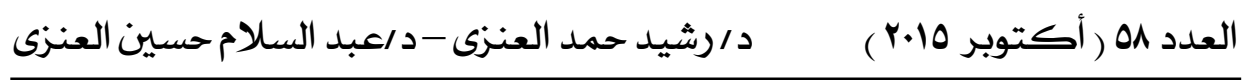

\section{أولاً : التفرقة بين المقاوهة المسلحة والإرهاب}

كثير ا ما يختلط مفهوم الإرهـاب بأنشطة المقاومـة المسلحة ممـا يستلزم التميز

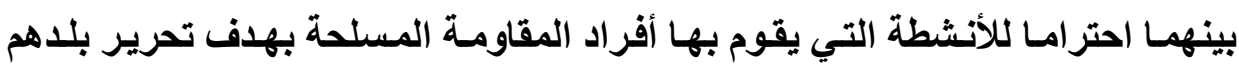

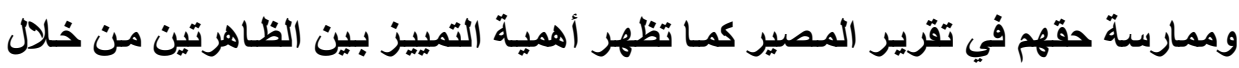
عدم السماح للاول والأنظمة المستعمرة بالقضاء على المقاومة المسلحة وحرمانها من فئن

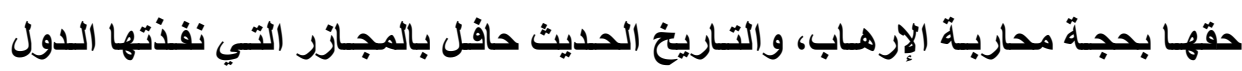
الاستعمارية في حق شعوب الدول المستعمرة والتي راح ضحيتها عشرات الآلاف من من الضحايا .

اختلف الفقـه في تعريـف الإرهـاب وذلـك نظراً لـصعوبة إيجـاد تعريـف محدد

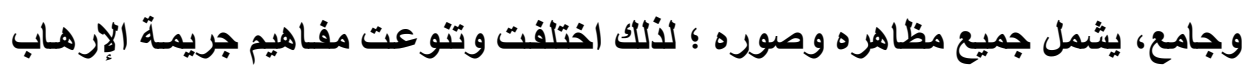

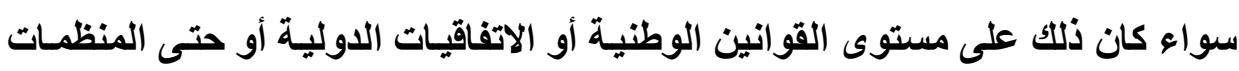
العالمية.

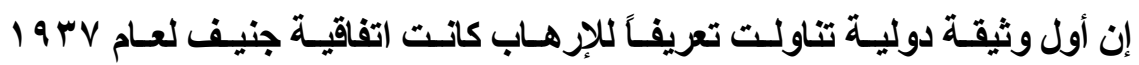

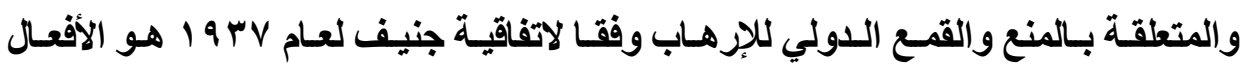

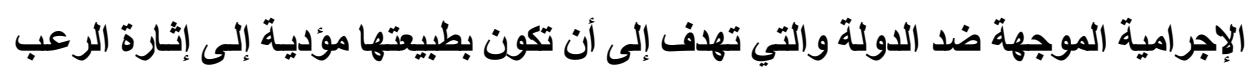

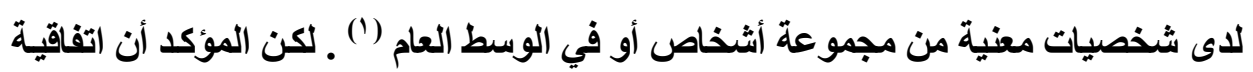

(1) Convention for the Prevention and Punishment of Terrorism, Nov. 16, 1937, League of Nations Doc. C.546M.383 (1937), reprinted in Manley O. Hudson (editor), International Legislation, vol. 7, (1941), p. 862

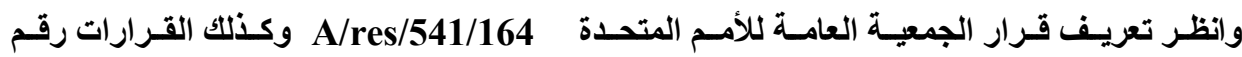

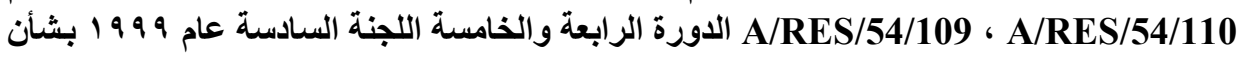

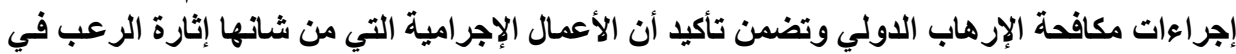

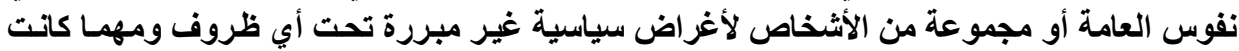

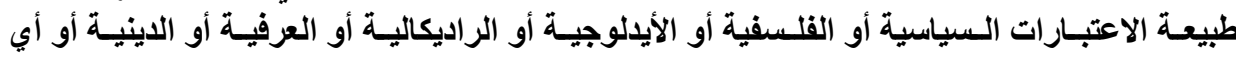

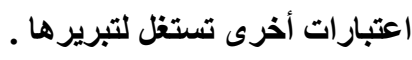

rی0 مجلت البحوث القانونيت والإقتصاديت 


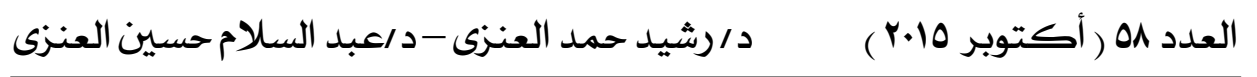

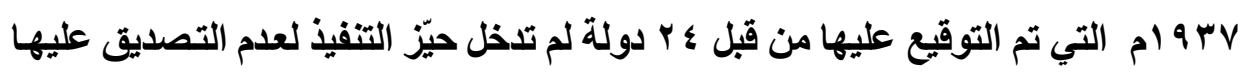

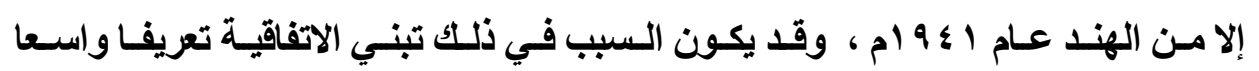

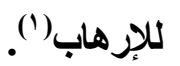

لكـن بسبب أحسداث الحسادي عشر مسن سـبتمبر وتـأثير اللـوبي الـصهيوني ، وإسرائيل على القرار الأمريكي في السنوات الأخيرة تداخلت فكرة المقاومـة والإرهـاب

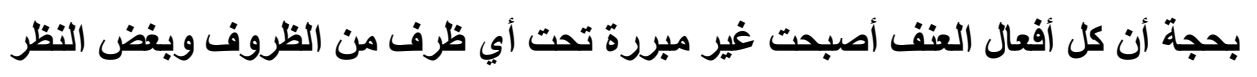

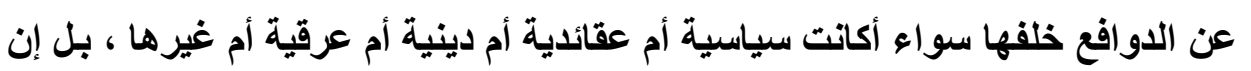
قرارات الجمعية العامة الأخيرة المتعلقة بالإرهاب لم تتطرق للحق في تقرير المصير ، وفي المقابل ترفض الكثير من الدول ، خصوصاً العربية والإسلامية الخلط بين الإرهـاب لابل

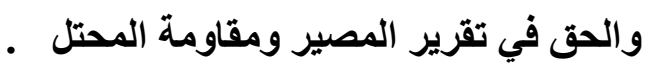

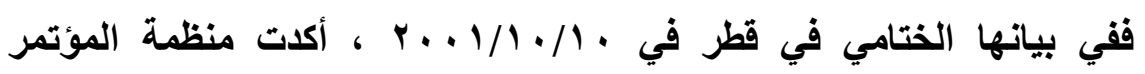
الإسلامي رفضها لأي ربط بين الإرهاب وحق الشعوب العربية والإسلامية في تقريز

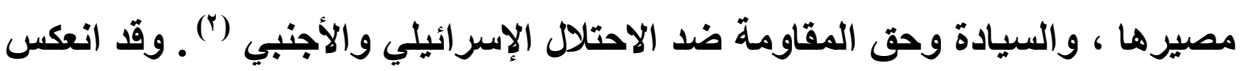
هذا التوجه في كل من الاتفاقية العربية لمكافحة الإرهاب واتفاقية منظمة المؤتمر ولاتئي الإسلامي لمكافحة الإرهاب (ل) . وقا يكون هذا التبيان أحد أهم أسباب تعثر الأمم المتحدة في التوصل إلى اتفاقية بثأن تعريف الإرهاب الاولي (')

(1) Reuven Young, Defining Terrorism: The Evolution of Terrorism as a Legal Concept in International Law and its Influence on Definitions in Domestic Legislation, Boston College International and Comparative Law Review, vol. 29, 2006, pp. 36-37

(2) Final Communiqué of the Ninth Extraordinary Session of the Islamic Conference of Foreign Ministers, Qatar, 10 October 2001, para. 6 citied in Foreign Policy January/February 2002, at p. 71

(1) Report of Ad Hoc Committee Established by General Assembly Resolution 52/210 of 17 December 1996, Sixth Session (28 January -1 February=

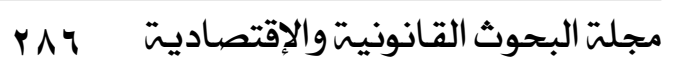


هذا وقد عرفت الاتفاقية العربية لمكافحة الإرهاب لعام 99 ام الإرهاب بأنه " كل فعل من أفعال العنف أو التهديد به أيا كاتت بواعثه أو أغراضه يقع تثفيذاً لمشروع إجرامي فردى أو جمـاعي ويهدف إلقـاء الرعب بـين النـاس ، أو ترويعهم ، بإيذأئهم أو تعريض

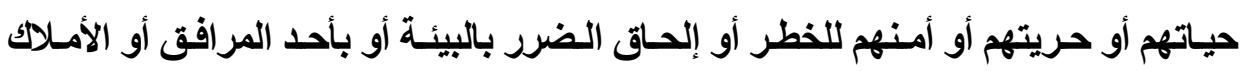
العامة أو الخاصة أو احتلالها أو الاستيلاء عليها أو تعريض أحد الموارد الوطنية للخطر " . وقد أكدت المادة الثانية من الاتفاقية العربية لمكافحة الإرهاب لعام 9 أم ام على أنه : لا تعد جريمة إرهابية ، حالات الكفاح بمختلف الوسائل بما في ذلك الكفاح المسلح ضد الاحتلال الأجنبي والعدوان من أجل تحريز وتقرير المصير وفقا لمبادئ القانون الدولي ولا يعدّ من هذه الحالات كل عمل بالوحدة الترابية لأي من الدول العربية " .

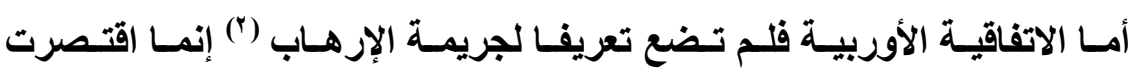

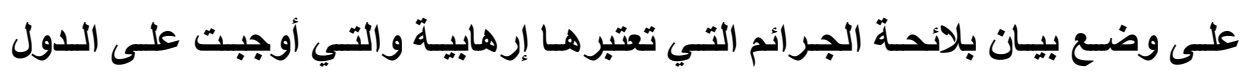

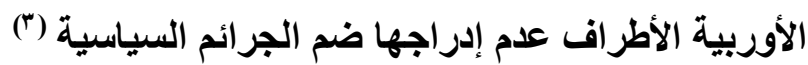

= 2002), GAOR, Fifty-Seventh Session, Supplement No. 37 (A/57/37), Annex IV, Texts Related to Article 18 of the draft Comprehensive Convention, :Text Proposed by the Member States of the Organization of the Islamic Conference', para. 2.

$\left(^{2}\right)$ Sabine von Schorlemer, Human Rights: Substantive and International Implications of the War Against Terrorism, EJIL, vol. 14, 2003, 265 at pp. 271-272

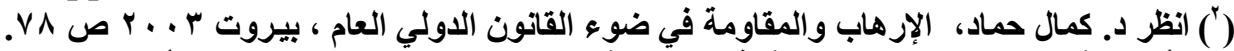

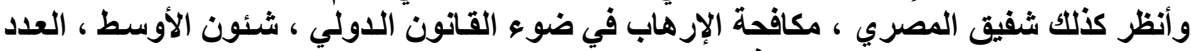

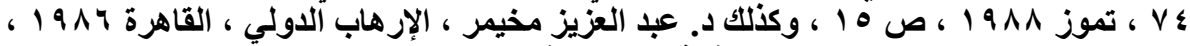

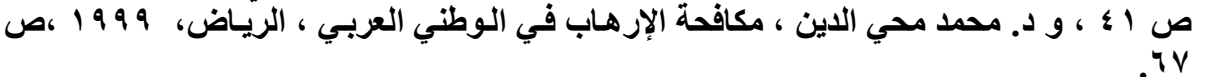

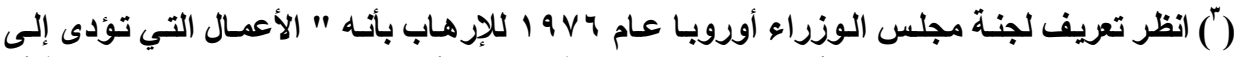

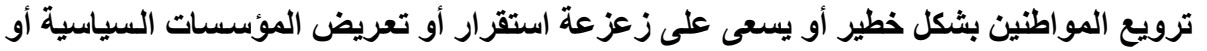

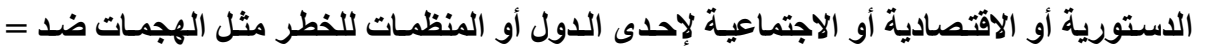


ومن خلال كل ما تقدم يتضح بـأن الإرهـاب يختلف عن المقاومـة المسلحة بـأن

الإرهـاب هو عمل إجرامسي موجـه ضـ المـنيين بهدف ترويعهم أو ضـد المؤسسـات

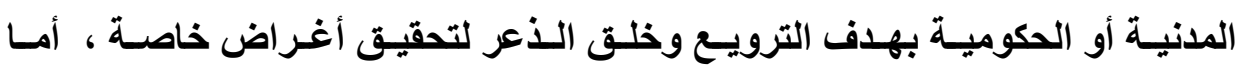

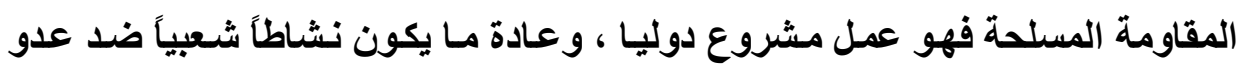
أجنبي بدافع وطني حيث إنّ الهدف من المقاومة المسلحة هو تحقيق التحرير أو الحق في تقرير المصير ، وتقوم هذه المقاومة من الشعب أو بعضه ويتأييد من باقي الثعب ،

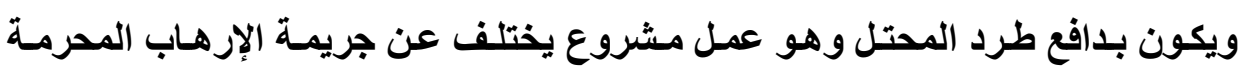

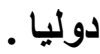

\section{ثانيا : التفرقة بين المقاوهة المسلحة والمقاوهة المدنية}

إذا كاتست القـوة المسلحة ومباثـرة العمليـات القتاليـة هـي أسـاس قيـام المقاومــة المسلحة فإن المقاومة المدنية Civil Resistance هي مقاومة تقوم بالاعتماد على عدة

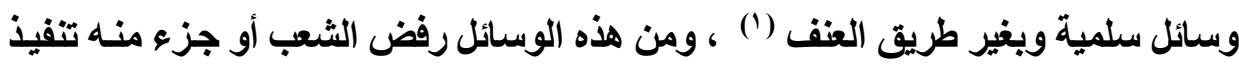
قرارات سلطة الاحتلال عن طريق العصيان المدني والقيـام بالمظـاهرات والإضراب عن العمل ، ومن أمثثة المقاومة المدنية في العصر الحديث المقاومة التي قادهـا الزعيم المهاتمـا غاندي في الهند ضد الاستعمار البريطاني والتي توجت بالحصول على الاستقلال () ، كنلك

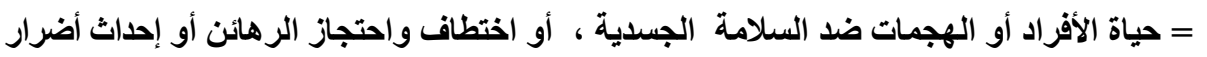

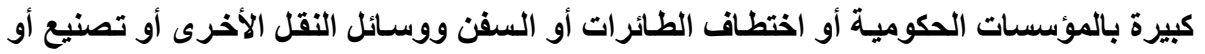

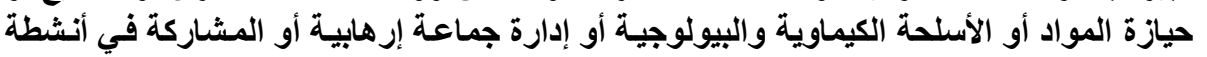

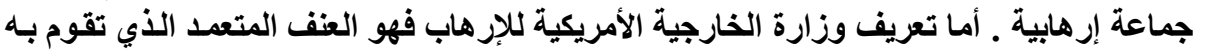

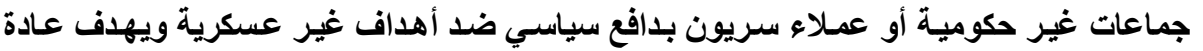

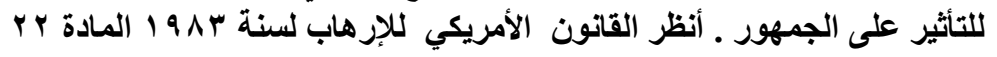

(1) Roberts, A ,Civil Resistance as a Technique in International Relations, the Yearbook of World Affairs , 1970, pp.25

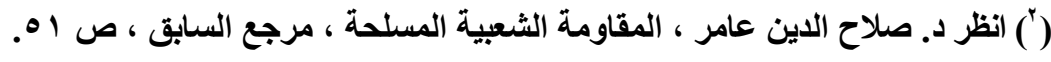

r^^ مجلة البحوث القانونيت والإقتصاديت 


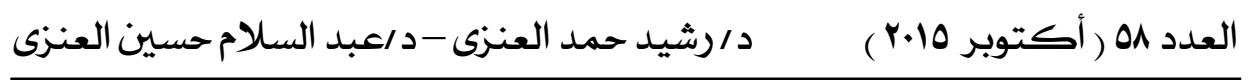

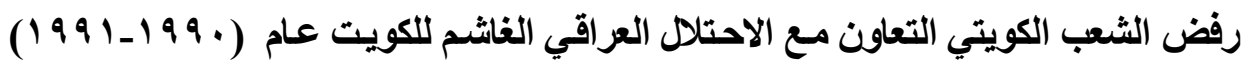

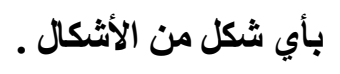

\section{ثالثا : التفرقة بين المقاوهة المسلحة والحرب الأهلية :}

من العناصر المهمة في المقاومة المسلحة إنها تقوم ضد قوات أجنبية محتلة ، ومن ثم يخرج من هذا المفهوم الصراع المسلح بين قوات متمردة والسلطة الحاكمـة أو بين الشعب والحكومة أو أي طرفين متضادين يلجآن إلى السلاح في داخل الدولة ذاتها ، فهذا الصراع ياخل ضمن مفهوم الحروب الأهلية الخاضعة للبروتوكول الثاني لسنة 9 VV العمليات العدائية التي تجرى في إطار دولة واحدة ، وتوجد عندما يلجأ طرفان متضادان

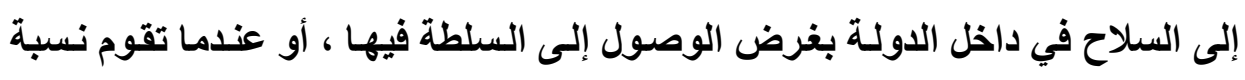
كبيرة من المواطنين في دولـة بحمل السلاح ضد حكومتها (') وهنـا تبرز التفرقة بين المقاومة المسلحة والحروب الأهلية ، حيث إنها إذا كان من يجرى ضده أعمال المقاومة

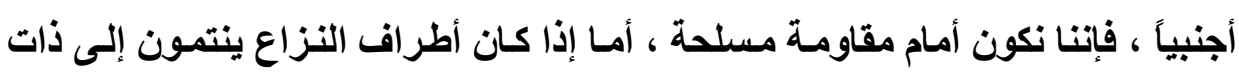

$$
\text { الدولة فإنتا نكون أمام حرب أهلية . }
$$

هذا وقد ذهب القضاء الفرنسي إلى تكييف النزاع المسلح الذي نجم عن أعمال

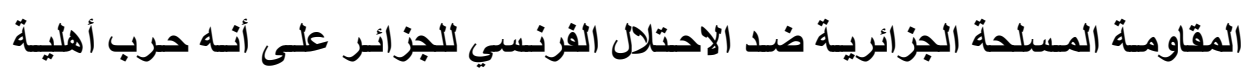

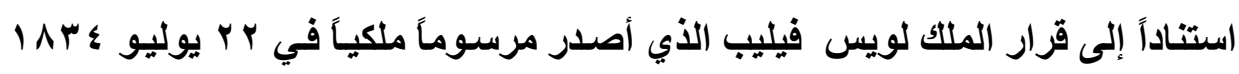

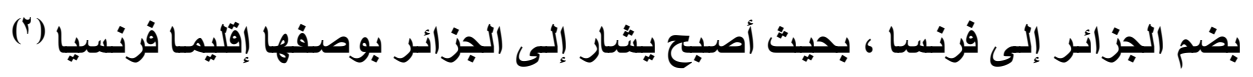

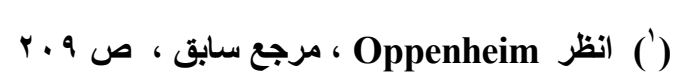

(2) Pinto Roger, les Regles du Droits International concernert la Guerre Civil, Recueil des cours de l'Academie de Droit interntional de la Haye, 1956-1,tome114, pp.462.

r^9 مجلت البحوث القانونيت والإقتصاديت 
بينما ذهب جاتب كبير من الفقه الفرنسي إلى القول بعدم توافر وصف المحساربين لثوار الجزائر ، ومـن ثم فـإن الأحداث التـي جرت لـم تكن تعدو كونهـا عصياناً داخلياً ممـا يخضعها لقانون العقوبات (') ـ بينما عارض القاضي في محكمة العدل الدولية الجزائري محمد بياجاوى هذا الفقه ، بقوله : إنّ وصف الحرب الأهلية توجد حيثــا يلجـأ طرفـان

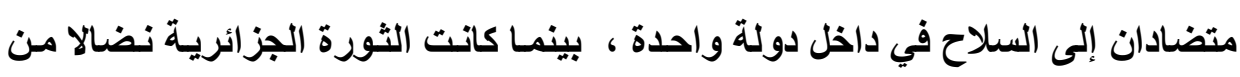
جاتب الشعب ضد عدو محتل بهدف الحصول على حقه في تقرير مصيره (") . ومع ذلك فإن تكييف العلاقة هذه هو لأغراض القانون الفرنسي الاخلي ، وليس

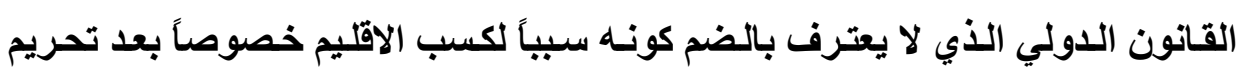

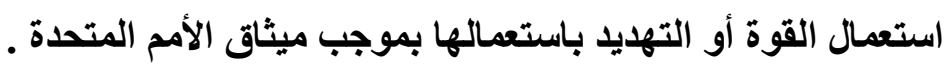

\section{رابعا : التفرقة بين المقاوهة المسلحة والعصابات المسلحة في ظل الاحتلال :}

إن العصابات المسلحة هم جماعة من الأفراد منظمة على شكل عصابات مسلحة ويقومون بأعمـال عنف عن طريق استعمال السلاح بهدف السلب والحصول على مغانم خاصة في مواجهة سلطه تقوم باحتلال الوطن (") ، فقي هذه الحالة يبدو من الصعب التمييز بين اللصوصية والوطنيـة، حيث تلعب مثثل هذه العصابات دورا مزدوجـاً بكونها تستعمل السلاح من أجل السلب والسرقة ولكن بالمقابل تنـال من أمن دولة أجنبية محتله لأراضي الوطن وتقف تلك الدولة المحتلة موقف العداء من الشعب ـ هذا وقد يلجـأ أفراد المقاومـة المسلحة إلى أعمال السطو والنهب ضد قوات الاحتلال ، وذلك إمّا لتوفير المؤن والأسلحة

(') Ford w.j, Les Members des mouvements de resistance international, Extrait de la revue internationale de la croix- rouge, geneve, octobre, nouvembre, Decembre 1967- janvier 1968,pp. 28.

${ }^{2}$ ) Bedjaoui Mohamed, la revolution algerienne et le droit, Edition de l'association internationale des juristes Democrates, 1961, P.161 .

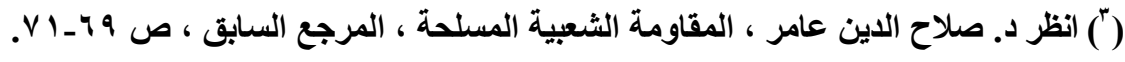

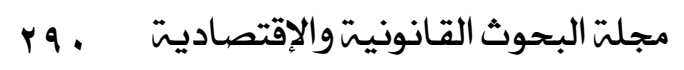




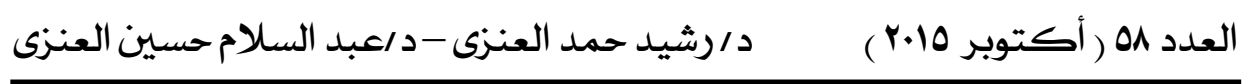

والذخائر لمواصلة كفاحها المسلح وإمّا نتيجة لانحراف بعض أفراد هذه الحركة ، وهنـا تبرز صعوبة التمييز بين المقاومة المسلحة والعصابات المسلحة .

ونحن نرى أنه يمكن التمييز دائماً بين حركة المقاومة المسلحة وأعمال العصابات المسلحة ، بالاعتماد على معيار الدافع الوطني الذي يتوافر في الأولى دون الثاتية ، وحتما في حالة المثال السابق فإن أفراد المقاومة المسلحة لا يفقدون صفتهم هذه إلا إذا تحولوا كلية عن الهدف الوطني إلى أعمال السلب والنهب لصالحهم الخاص، أما إذا كان ارتكاب مثل هذه الأعمال بهدف الاستمرار في نشاط المقاومة لتحقيق أغراضها وأهدافها النهائية فإنهم لا يفقدون صفتهم ، ولا يؤثر ذلك في طابعهم

ووصفهم بالمقاومة المسلحة التي تسعى إلى الاستقلال (')

\section{خامسا : التفرقة بين المقاومة المسلمة وحروب الانفصال :}

إن انفصال إقليم من أقاليم الدولـة ليصبح بذاتـه دولة مستقلة عن الدولـة الأم

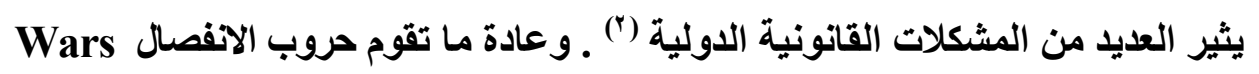
of Secession

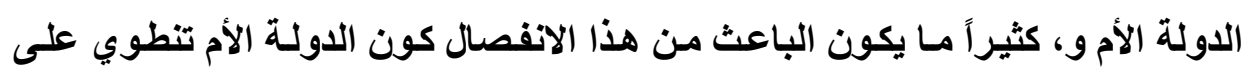

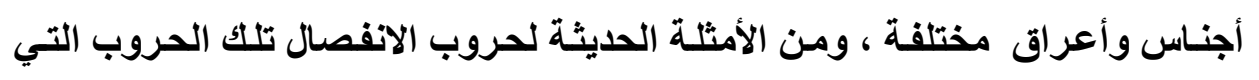

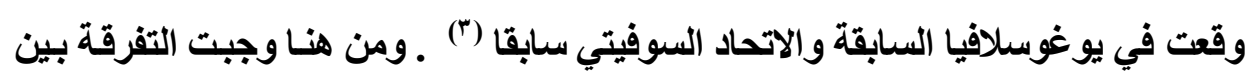

$$
\text { (') (') المرجع السابق. (انظر في انفصال الدول }
$$

D.P O'Connell, the Law of State Succession, Cambridge University Press, 1956, p. 425. 


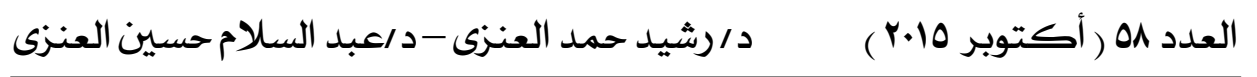

حروب الانفصال ، وحركة المقاومـة المسلحة وهى مقاومـة تواجه دائمسا عدوا أجنبيا قـام باحتلال أرض الوطن بينما حروب الاففصال تجرى دائما ضد حكومـة الدولة ذاتها ، التي لا تعدّ أجنبية قبل الانفصال ، ولكن متى أقيمت دولة جديدة ، وتم تأسيس حكومـة لإدارة شئون هذه الدولة ، واعترف المجتمع الدولي بهذا الوضع الجديد هنـا تصبح الدولـة الأم سلطة أجنبية أما قبل ذلك فلا يعدو الوضـع إلا نزاعـا داخليـا وطنيا يختلف عن المقاومـة المسلحة

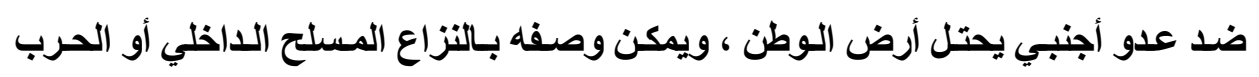
الأهلية متى توافرت شروطه (')

C.Schmidt, sur quelques questions de succession possees par la dissoution de la Yougoslavie et celle de $L^{\prime}$ ' U.R.S.S, Reuve Generale de Droit international public, 1992,p.811-842.

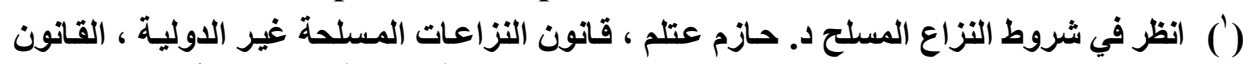

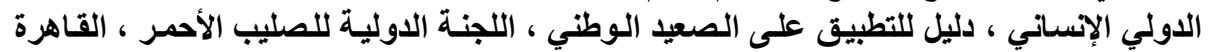

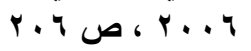

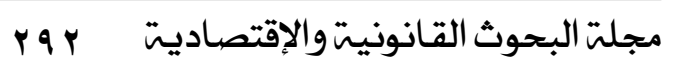




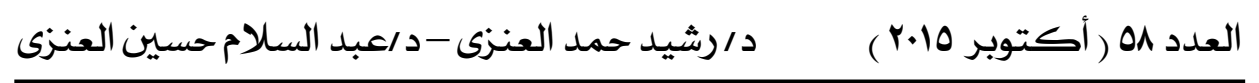

\section{المبحث الثاني}

\section{هشروعية استعمال القوة هن قبل أفراد المقاوهة المسلحة}

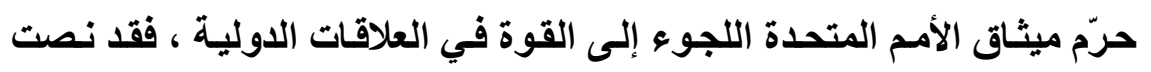

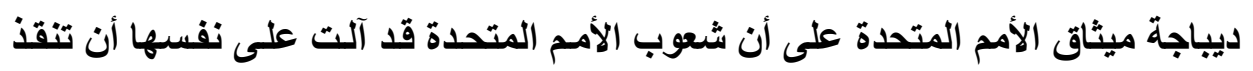

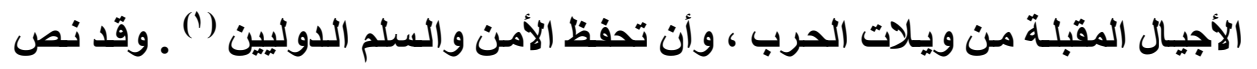

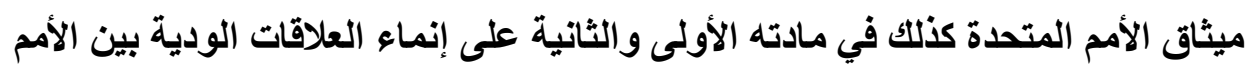

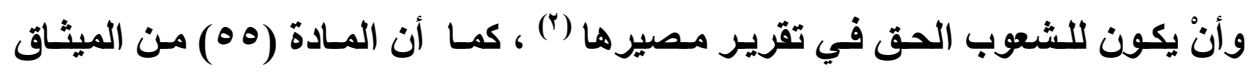

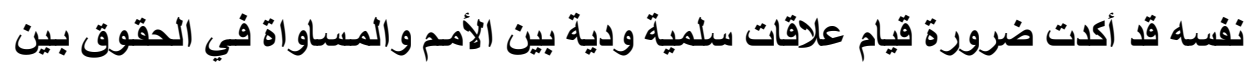

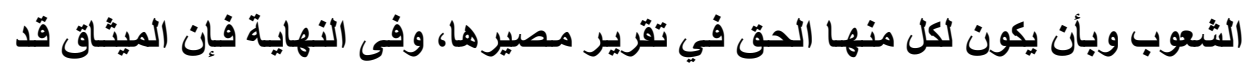

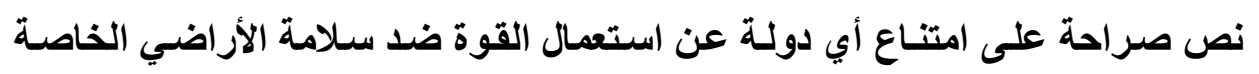
بالدول الأخرى (")

وعلى الرغم من عمومية مصطلح " تحريم استعمال القوة " التي نص عليه

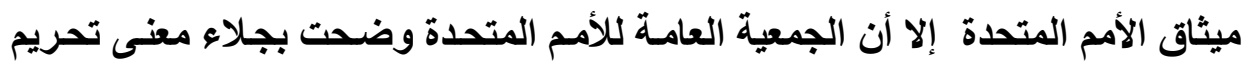

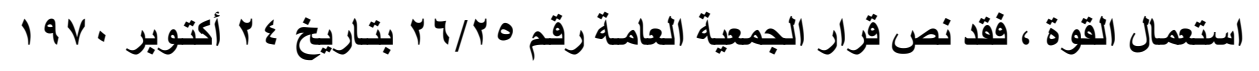

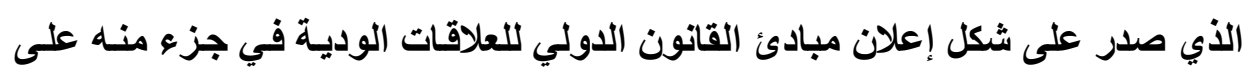

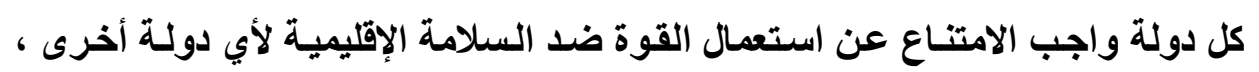

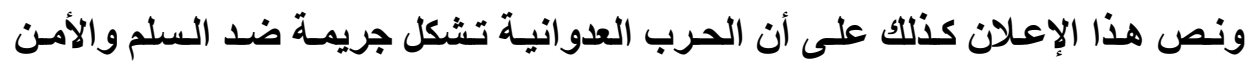

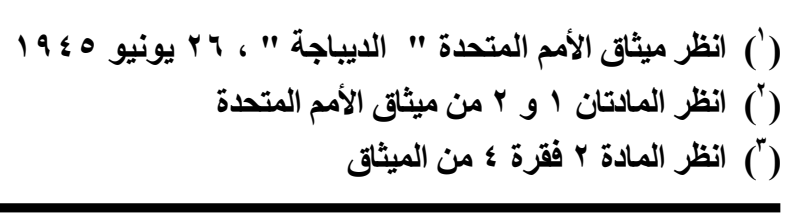

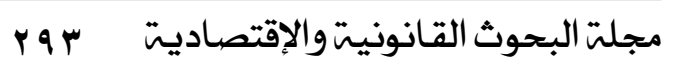




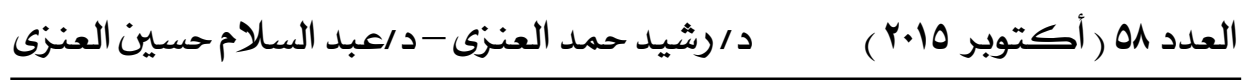

الدولي، وأنّ اسـتعمال القوة لخـرق الحدود الدوليـة لدولـة أخرى أو إخضاع إقليمهـا لاحتلال عسكري ، أو اكتساب إقليم لأي دولة أخرى نتيجة استعمال القوة يعدّ انتهاكاً

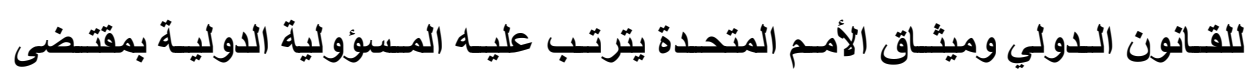
قواعد القانون الدولي (')، وبذلك يمكن القول : إن استعمال القوة المسلحة لاحتلال إقليم دولة أخرى أصبح اليوم يتعارض مع قواعد القانون الدولي () ، بل أن تحريم اللجوء إلى القوة في النزاعات الدولية أصبح يشكل قاعدة آمرة لا يمكن الاتفاق على مخالفتها

وقد نص الميثاق كذلك على احترام حق الشعوب في تقرير مصير ها ممـا يعني

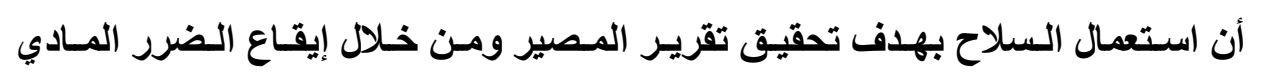
والمعنوي بسلطة الاحتلال ومنشآته يعدّ من قبيل الأعمـال المشروعة وفقـا للقـانون الدولي، بل إنّ مشروعية المقاومـة المسلحة ذاتها أصبحت من القواعد الراسخة في القانون الدولي الإنساني ، هذا ويجوز استخدام أي نوع من أنواع الأسـلحة التقليديـة المصرح بها دولياً لإيقاع الضرر بقوات جيش الاحتلال وآلياته ومنشاته العسكرية بغية إرغام المحتل على الانسحاب .

(') (انظر نص الإعلان في د. محمد يوسف علوان ، القانون الدولي العام ، وثائق ومعاهدات دولية ، عمان،

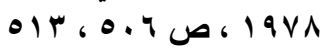

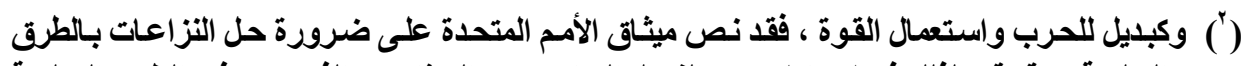

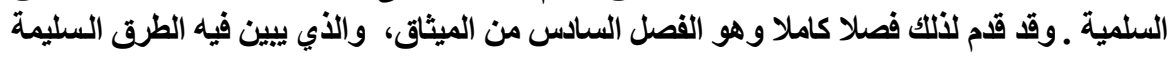

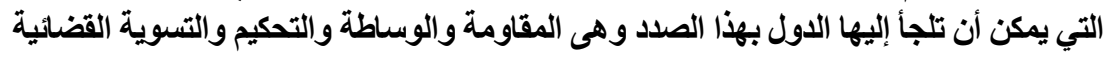

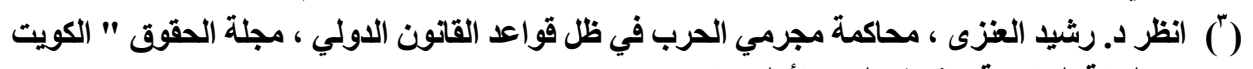

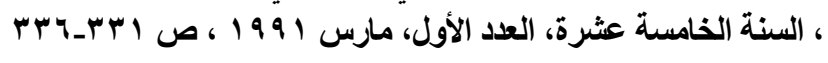

مجلمت البحوث القانونيت والإقتصاديت 


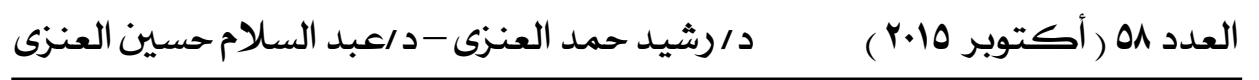

ولذلك فسوف نتناول في هذا المبحث حق تقرير المصير باعتباره استثناء على تحريم اسـتعمال القـوة في المطلب الأول والـدفاع الشرعي والمقاومـة المسلحة في في

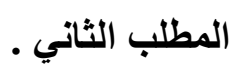

\section{المطاب الأول}

\section{هق تقريز المير استثناء هن تهريه استعمال القوة}

جاء حق تقرير المصير في ميثاق الأمس المتحدة حيث جـاعت الإشـارة إليه في

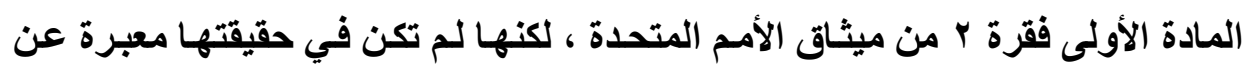
طبيعة الحق .

وعلى خـلاف ميثاق الأمـم المتحدة جـاعت قرارات الجمعيـة العامـة التي يهيمن

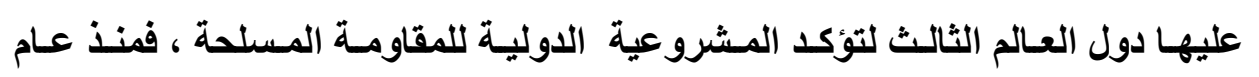

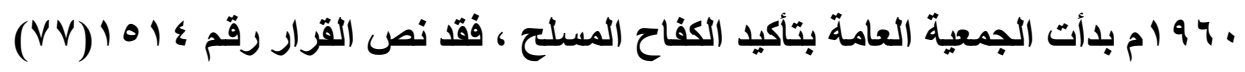

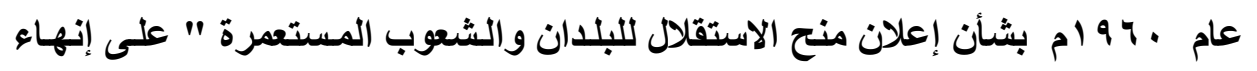

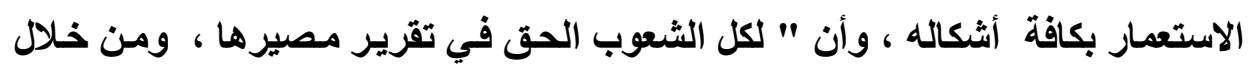

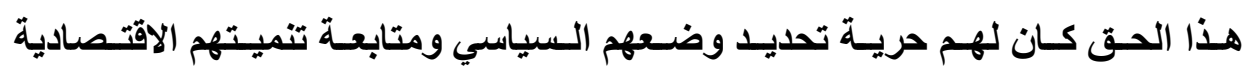
والاجتماعية والثقافية" ثم توالت بعد ذلك قرارات الجمعية العامـة في فترة الستينيات

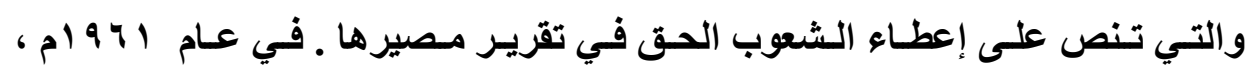

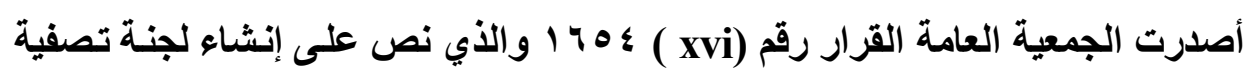

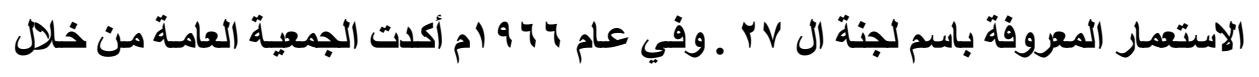
القرار رقم (xxi) 2189 بأن بقاء النظام الاستعماري يضع الأمن والسلم الدولي في خطر 


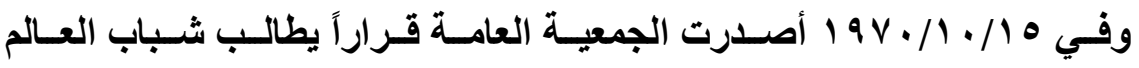

بالوقوف ضد أي عمل عسكري وغير عسكري يهدف إلى القضاء على حركات الشعوب التي ماز الت تعاني من سيطرة استعمارية أو عنصرية أو أجنبية أو ترزح تحت نير

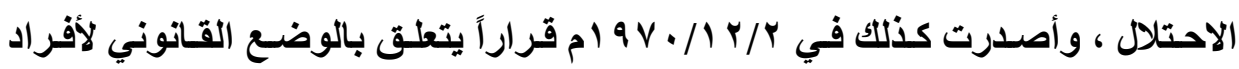
المقاومسة ، وضـرورة معـاملتهم بوصـفهم أسـرى حـرب وفقاً لاتفاقيـات جنيـف لعـام

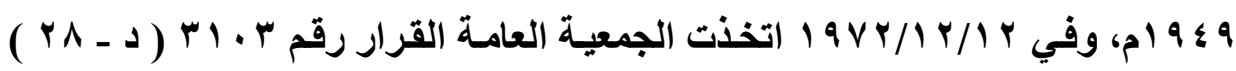
أكدت من خلاله عدداً من المبادئ الأساسية التي تتعلق بالمركز القانوني للمقاتلين الأين

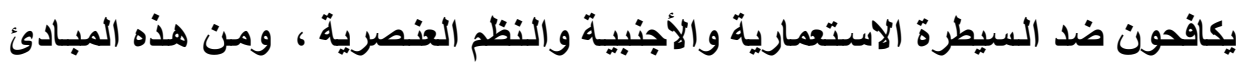
اعتبار كفاح الشعوب لتقرير مصيرها كفاحاً مشروعاً يتفق مع مبادئ القـانون الدولي ،

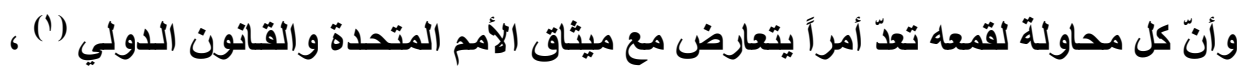
ومن الملاحظ أن هذا القرار قد احترم ولأول مرة شرعية الكفـاح المسلح للشعوب ،

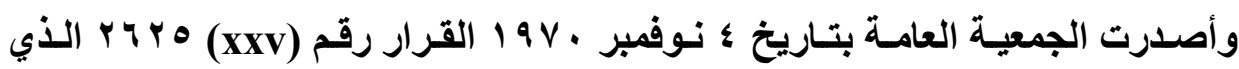
ينص على أن " لا يجوز لأي دولـة استخدام القوة لمنع الشعوب من حقها في تقرير مصيرها حتى لو كانت هذه الشعوب تقاوم المحتل بالوسـائل كافة متى مـا كاتت تلك لك المقاومة تلخل في دائرة حقها في تقرير مصيرها " (َ) ثم صدر بعد ذلتك القرار رقم

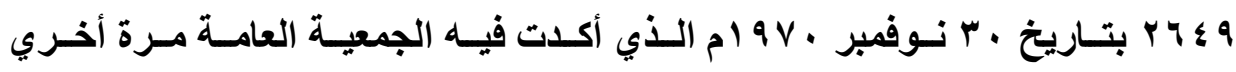

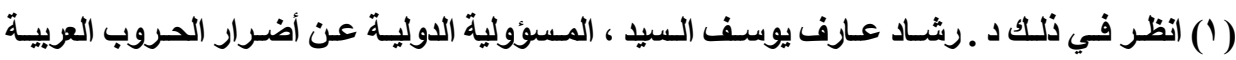

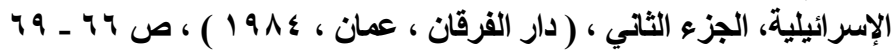

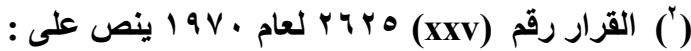

"Tout Etat a le droit de s' absentir de recourir a toute mesure de coercition qui priverait les peuples.... De leur droit a diposer d'euxmemes, de leur liberte et de Independence. losqu' ils reagissent et resistent a une telle mesure de coercition dans l'exsercice de leur driot a diposer d'eux - memes, ces peoples sont en droit de cherche et de recevoir un appui conforme aux buts et principes de la charte".

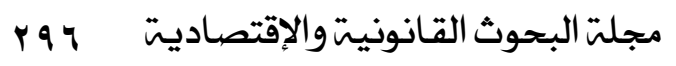




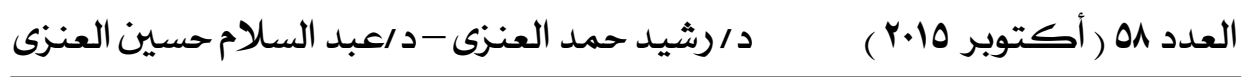

مشروعية نـضال الشعوب الخاضـعة للاستعمار أو السيطرة الأجنبيـة والمعترف لهـا بحقها في تقرير مصيرها ، باسترداد ذلك الحق بالوسائل كافة المتاحة لها ( ' .

هذا وعادت الجمعية العامة مرة أخرى لتؤكد مشروعية نضال الشعوب من أجل

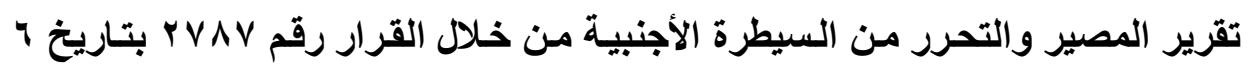
ديسمبر I9VI حيث نص هذا القرار على حق شعوب زامبيا ، وناميبيا ، وانجولان

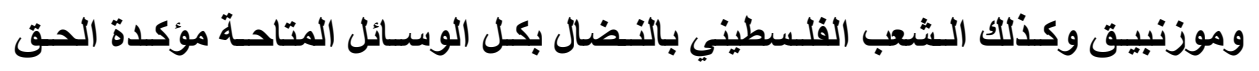

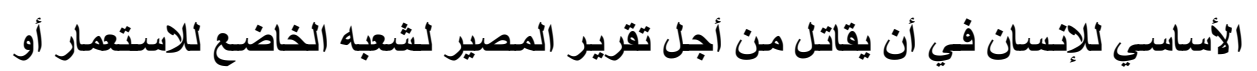
السيطرة الأجنبية ، ولم تقتصر الجمعية العامة على تقرير المبدأ فحسب ، ولكنها ذهبت التبن إلى أبعد من ذلك بدعوة الدول والمنظمات الدولية ؛ لتقديم كل وسائل الدعم المادي إلى الى

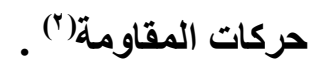

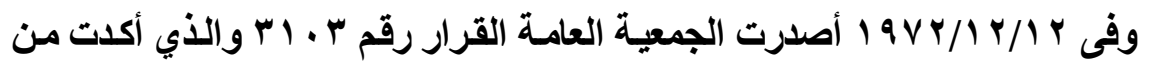

خلاله عدداً من المبادئ الأساسية التي تتعلق بالمركز القانوني للمقاتلين الأين يكافحون ضد السيطرة الاستعمارية والأجنبية والنظم العنصرية ، ومن هذه المبادئ اعتبار الكفاح المسلح

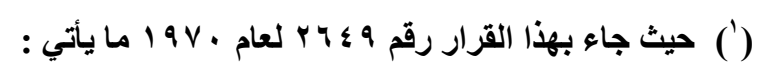

"The General Assembly...

1- affirm the legitimacy of the struggle of peoples under colonial and alien damnation recognized as being entitled to the right of self determination to restore to themselves that right by any means at their disposal ...."

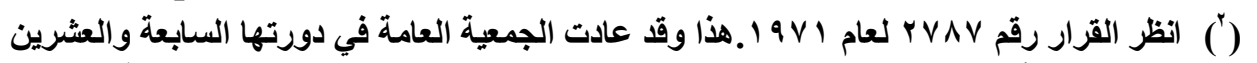

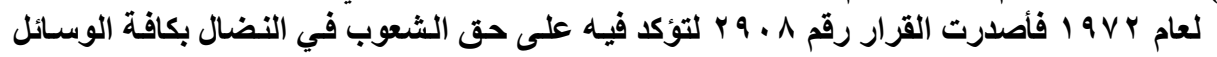

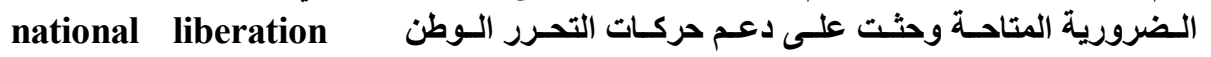

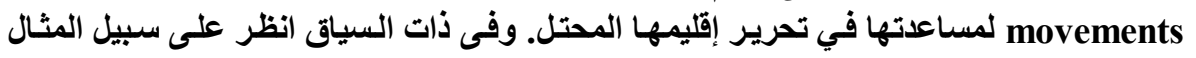

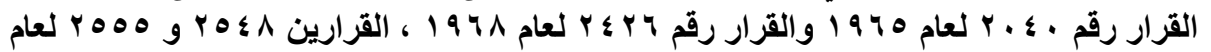

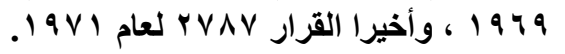

rqv مجلت البحوث القانونيتوالإقتصاديت 
العدد هo ( أكتوبر 10.r. ) د/رشيد حمد العنزى -د اعبد السلام حسين العنزى

للشعوب لتقرير مصير ها كفاحاً مشروعا يتفق مع مبادئ القانون الدولي ، وأنّ كل محاولة

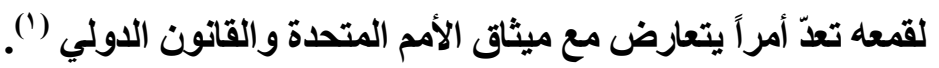

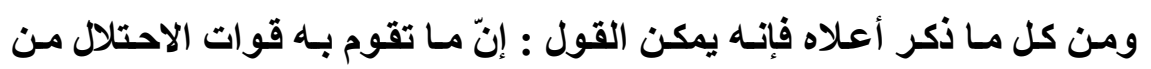

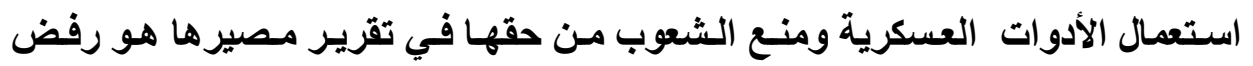

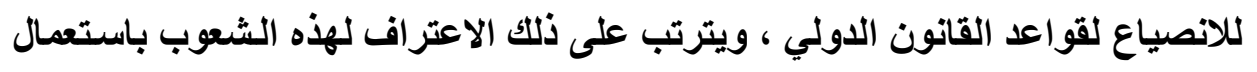

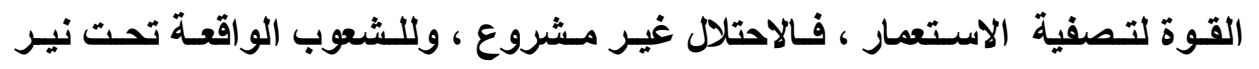

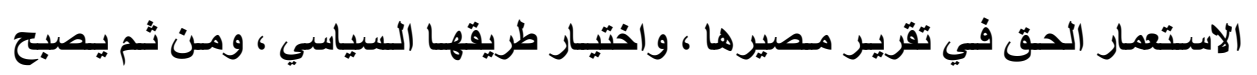

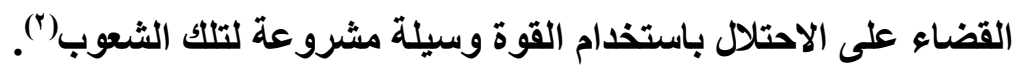
ويمكن القول كذلك إنّ الجمعية العامـة للأمـم المتحدة قد أسست قاعدة عرفيـة

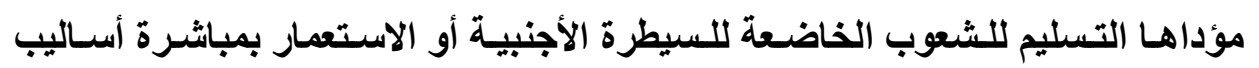

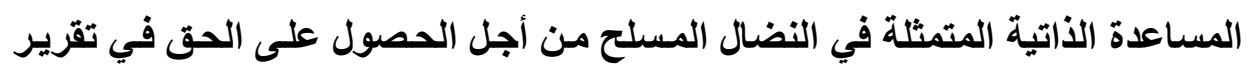
المصير ، والقضاء على الاستعمار أو التسلط الأجنبي .

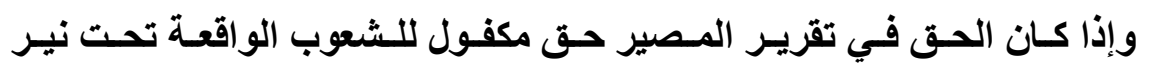

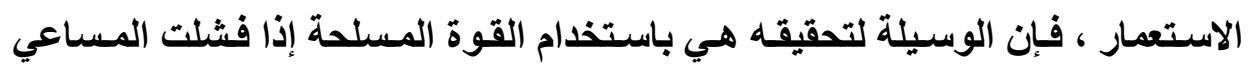

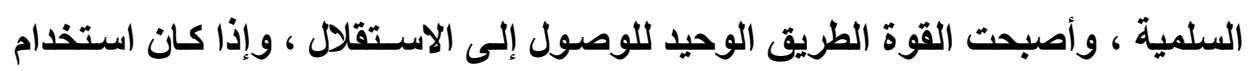

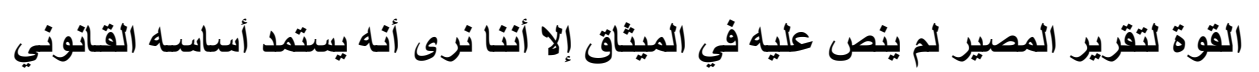

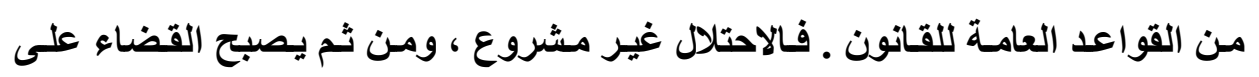

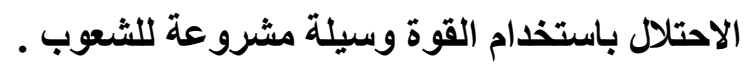

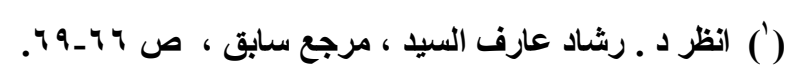

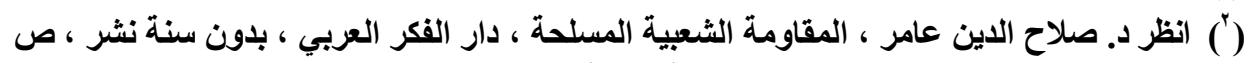

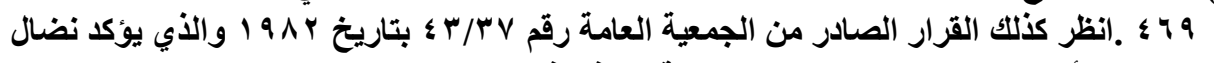

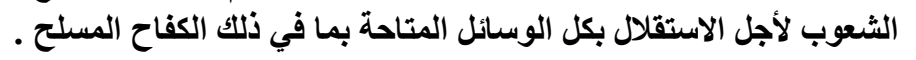

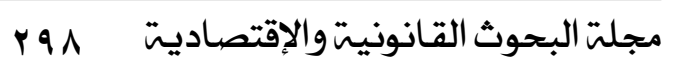


هذا وقد قام مجلس الأمن بدعم هذا التوجه من خلال العديد من قراراته ـ فقد أكد

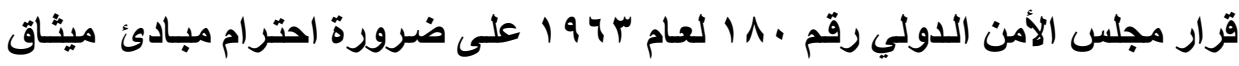

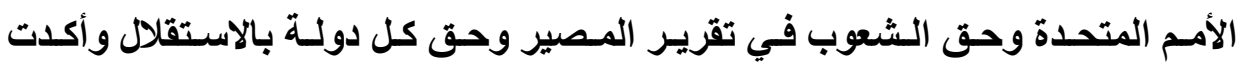

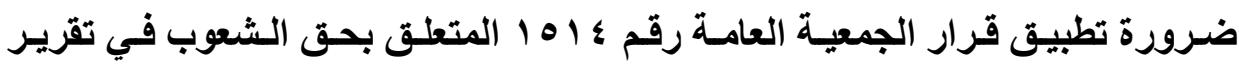

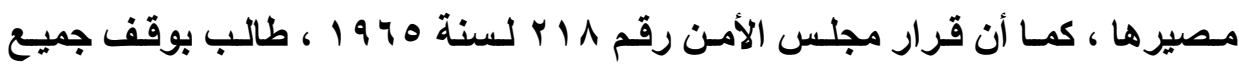

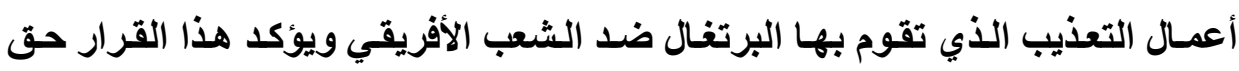

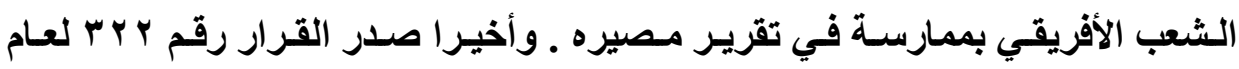

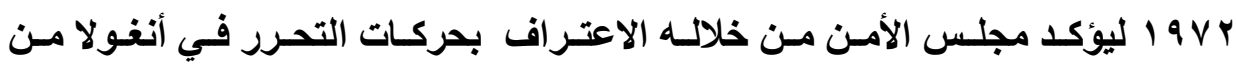

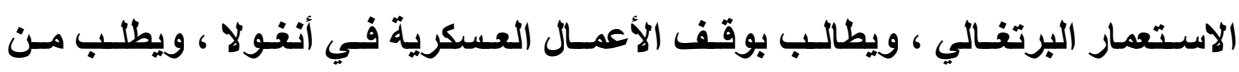

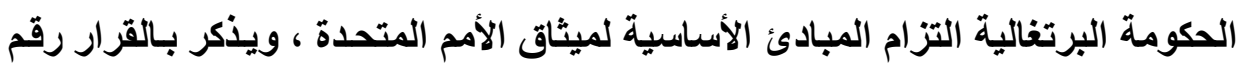

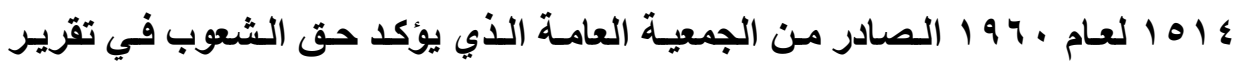
مصيرها ويدعم حقها في الاستقلال.

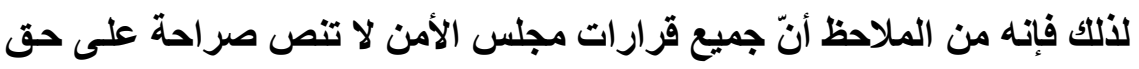

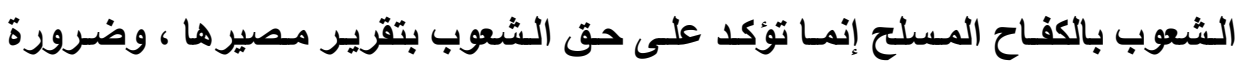

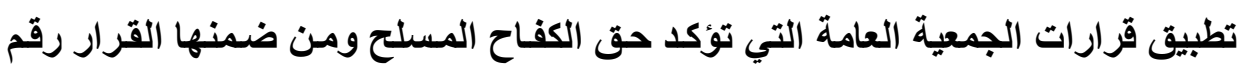

وعلى صعيد الاتفاقيات الدولية فقد تمّ تأييد حق تقرير المصير في المادة الأولى

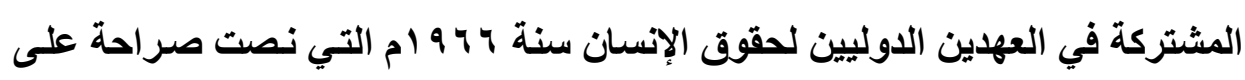
حق الثعوب في تقرير مصيرها (') 


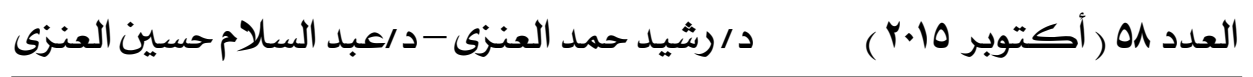

كذلك اعترفت اتفاقيـة جنيـف الثالثة لسنة و ؛ 9 ام والبروتوكـول الأول لعسام ا 9VV

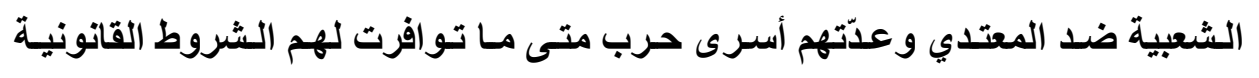
لإضفاء صفة المقاتلين عليهم على ما بيناه أعلاه .

ونتيجـة للتطورات الدوليـة على مـا أوضـحناه سـابقاً ، وبخاصـة تلكـ المتعلقة

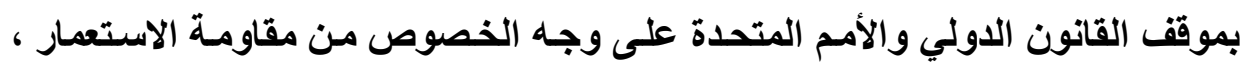

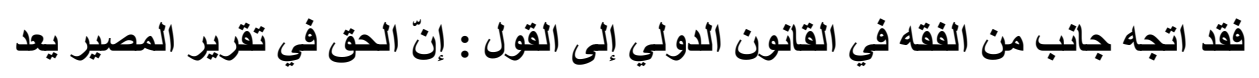

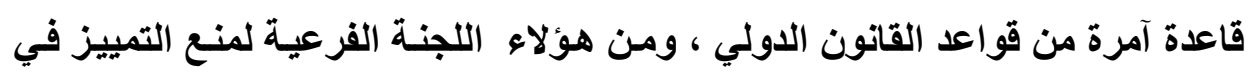
الأمم المتحدة التي ذهبت في تقريرها عن الحق في تقرير المصير إلى ذلك حيث قالت اللجنة الامن

" no one can challenge the fact that, in light of contemporary international realities, the principle of self determination necessarily possesses the character of jus congens ${ }^{(')}$.

ويقول البروفسور (إيان براونلي) إنه يجب منح المقاتلين الذين يقاتلون في

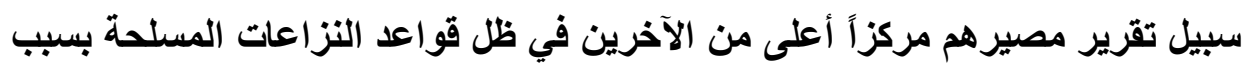

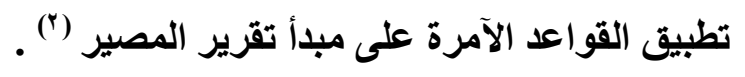

(1) Espiell, Hector Gros, the Right to Self- Determination : Implementation of United Nations Resolutions - Study Prepared by Hector Gros Espiell, Special Rapporteur of the Sub-Commission on Prevention of Discrimination of Minorities . New York: U.N. Doc E/CN 4/sub. 2/405 rev. 1, UN . sales no. E79-x1 v.5 (1980), p.11-13.

(2) Ian Brownlie, Principles of Public International Law, (3 ed. 1979) p .83; Karen Parker and Lyn Neylon, Jus Cogens: Compelling the Law of Human Rights , Hastings International and Comparative law Review, vol. 12, (1989),p. 440-441

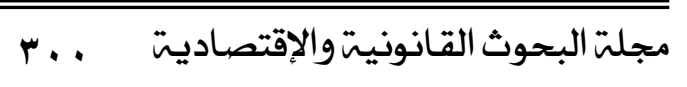




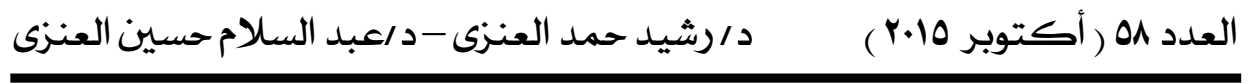

هذا وقد أكدت محكمة العدل الدولـة هذا المبدأ في أكثر مـن حكم لهـا. ففي

قضية الـصحراء الغربيـة Western Sahara أشسارت المحكمة إلى أن الحق في هي

تقريـر المـصير هـو حق للشعب ولـيس للحكومسات (') ـ وكـذلك في قضية ناميبيـا

سنة ا I I اعترفت المحكمة بطبيعة الحق في تقرير المصير باعتباره قاعدة آمرة من

قواعد القانون الدولي (). وفى هذه القضية اعترف القاضي (أمسن) في رأيه المستقل

بالصفة الآمـرة لقواعد الحق في تقرير المصير ، وفى قضية نيكـار اغوا والولايـات المتحدة الأمريكية عدّت المحكمة حق تقرير المصير من القواعد الآمـرة في القانون

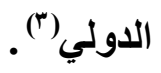

هذا وتجدر الإشارة إلى أن لجنة حقوق الإنسان التابعة للمجلس الاقتصادي

والاجتماعي نصت في قرارها الصادر عام 9 V ام على أن لجنة حقوق الإنسان تؤكد باستمرار شرعية النضال ضد الاستعمار بالوسائل المتاحة كافة بما في ذلك الكفاح المسلح.

(1) Western Sahara, Advisory Opinion, 1.C.J. Reports 1975, p. 12 at p. 31

$\left(^{2}\right)$ Legal Consequences for States of the Continued Presence of South Africa in Namibia (South West Africa) notwithstanding Security Council Resolution 276 (1970), Advisory Opinion, I.C.J. Reports 1971, p. 16.

$\left(^{3}\right)$ Military and Paramilitary Activities in and against Nicaragua (Nicaragua v. United States of America). Merits, Judgment. I.C.J. Reports 1986, p. 14; General Assembly Resolution No.A/ ReS /60/251,8 of May 2006; Resolution de la commission des droits de I 'home no. 3xxxv , 21 fevrir 1979 et resolution de la CDH. No. 1989 /19, 6 Mars 1989.

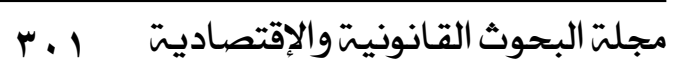




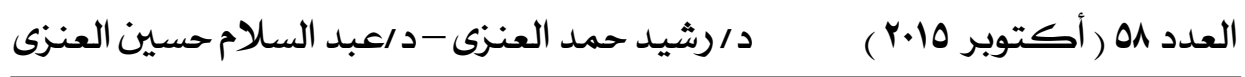

\section{الاطلب الثاني \\ الدفاع الشروي وهشروعية الاقاومهة المسلحة}

إن حالة الدفاع الثرعي من الحالات المعترف بها في القانون الدولي التقليدي

منــذزمـن بعيــ ويمكن القـول إنّ الاتصـالات التـي جـرت بـين الحكـومتين البريطانيـة والأمريكيـة في قضية السفينة كـارولين ^ب ^ ام تعبّر عن موقف القـانون الـدولي

التقليدي من حالة الدفاع الثرعي عن النفس(') .

وقد اقر ميثاق الأمم المتحدة حالة الدفاع الثرعي عن النفس ونظمها في المـادة

اه التي نصت على مـا يأتي : " ليس في هذا الميثاق مـا يضعف أو ينتقص الحق التق

الطبيعي للاول ، فرادى أو جماعات ، في الدفاع عن أنفسهم إذا اعتدت قوة مسلحة

على أحد أعضاء " الأمم المتحدة " وذلك إلى أن يتخذ مجلس الأمسن التدابير اللازمـة

لحفظ السلم والأمن الدولي ، والتدابير التي اتخذها الأعضاء استعمالاً لحق الدفاع عن

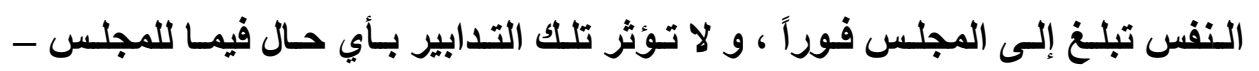

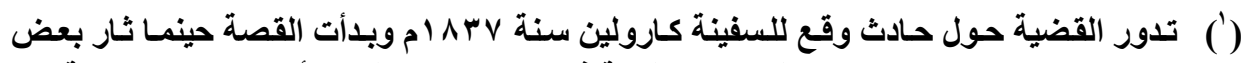

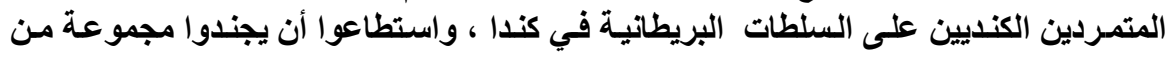

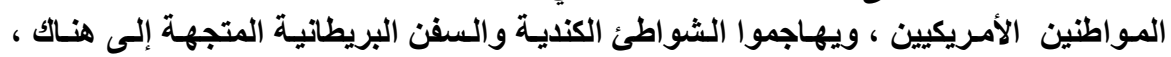

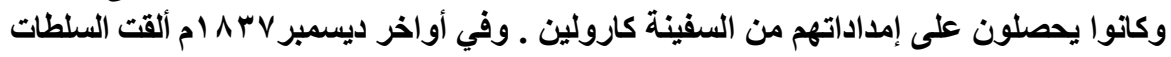

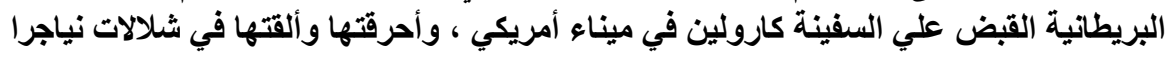

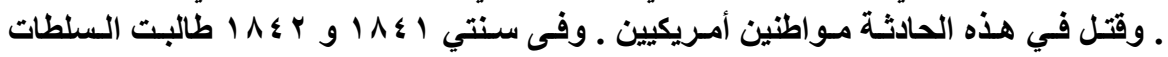

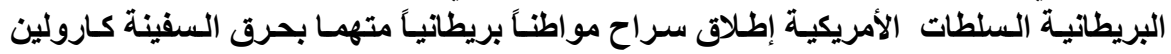

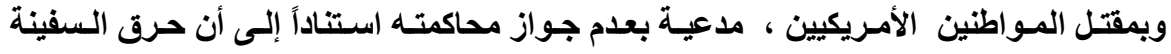

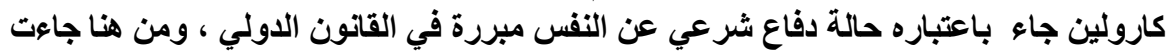

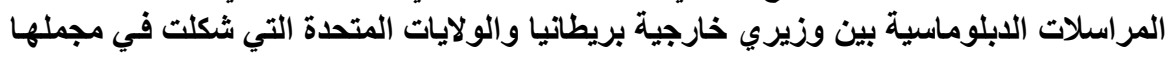

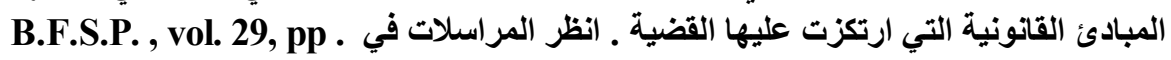

1137-1138

Shaw , International Law, $2^{\text {nd }}$. ed. (Cambridge, 1986), pp. وانظر كنلك

549-550.

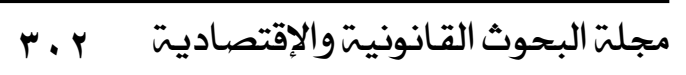




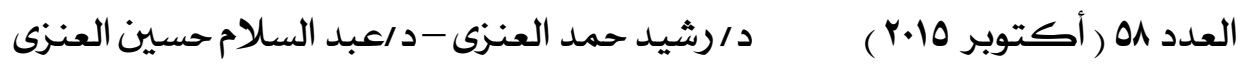

بمقتضى سلطته ومسؤولياته المستمدة من أحكام هذا الميثاق - من الحق في أن يتخذ

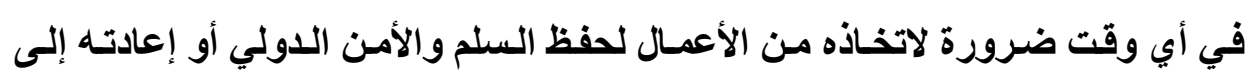

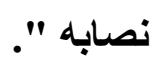

ولذلك نجد أن الميثاق يصف الدفاع المشروع عن النفس بأنه " حق طبيعي " ، ويعنى ذلك إنه حق للاولة تتمتع بـه دون تدخل أو تفويض من جهة أخرى ، فهو حق يثبت للاولة متى توافرت شروطه دون الحاجة إلى استئذان أي جهة أيا كاتت ـ وللاولة

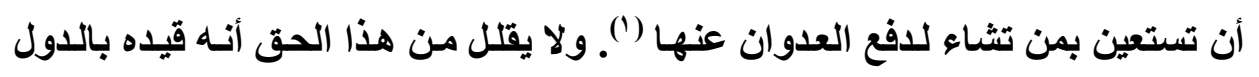
دون الشعوب ـ حيث إنّ الدول التي تقع تحت الاحتلال لا يمكن لها أن تدافع عن نفسها

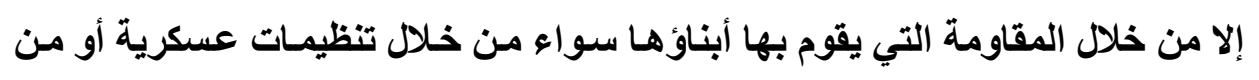
خلال تجمعات غير منظمة أو حتى من خلال أعمال فردية ـ فهو "حق طبيعي" ، أي انـه يستمد أساسه وشرعيته من القانون الطبيعي الأي يعطي الفرد والدولة حق الدفاع عن هن

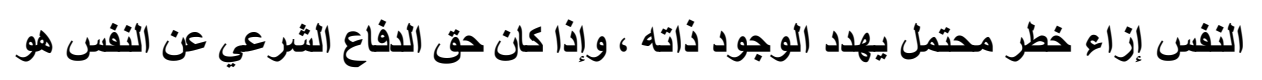
"حق طبيعي" فإنه من المنطقي أن تتمتع بـه الدول والتظيمـات العسكرية الشعبية والأفراد

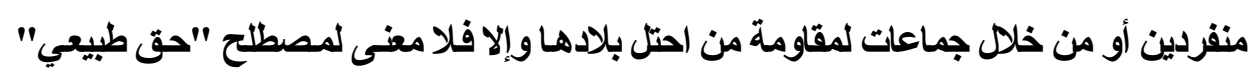
الواردة في المادة اهن من الميثاق .

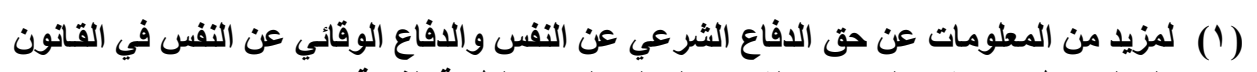

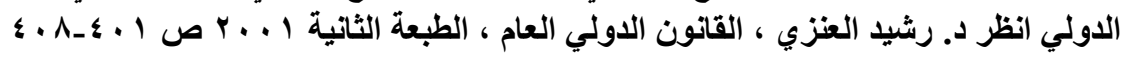

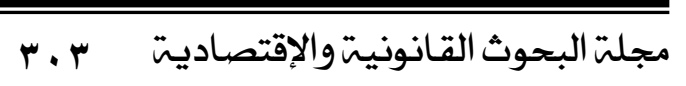




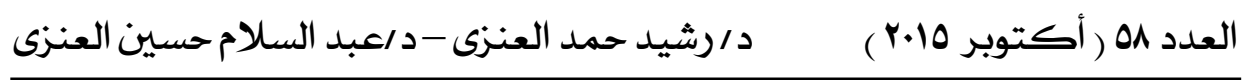

\section{الخاتمة}

أقر القـانون الدولي الإنساني للشعوب حق المقاومـة المسلحة ، بوصفها أداةً لطرد الاحتلال ، ولممارسة الحق في تقرير المصير ، حيث إنّ للشعوب الحق باختيـار الإني

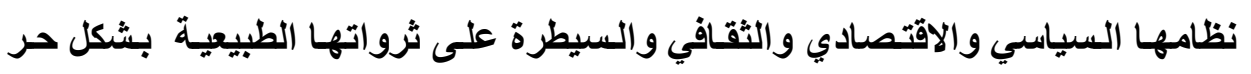

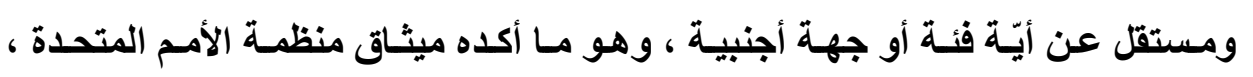
وقرارات الجمعية العامة للأمم المتحدة ، وقواعد القانون الدولي بثكل عام . إن المقاومة المسلحة ضد المحتل شغلت ومـا زالت تشغل المختصين بالقانون الدولي حول مفهومها ومشروعيتها ، ويقيت المقاومـة المسلحة ضد الاحتلال ، مدار جل ونقاش في أروقة المنظمات الدولية .

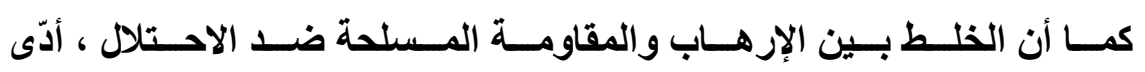
دوراً بارزاً في غموض مصطلح المقاومـة المسلحة والاتتقاص منهـا ، لكن شتان بين

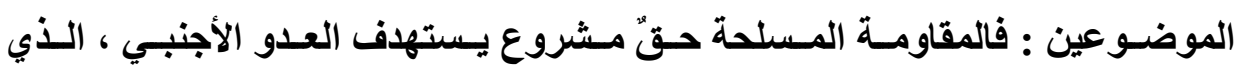

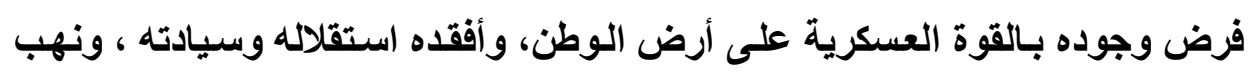

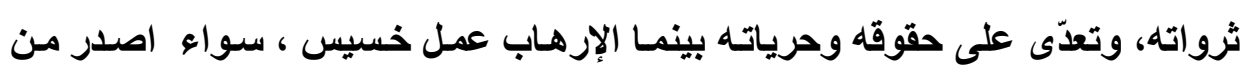
أفراد أم من أنظمة تستهدف إثارة الرعب ولا يفرق بين صغير ، ولا كبير ، ولا يميز بين مدني ، ومقاتل ؛ ولألك يدينه ويستنكره القانون الدولي بل يدعو إلى مكافحته بالوسـائل كافة .

وقد أدركت دول عدة أخطار الخلط بين الإرهـاب وبين المقاومـة المسلحة ، لا

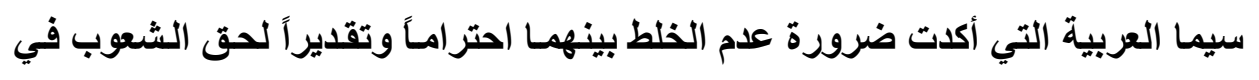
المقاومسة المسلحة ، وخصوصاً الشعب القلسطيني الــي يـن تحت وطـأة الاحتلال الاسر ائيلي الصهيوني لعقود طويلة .

مجلت البحوث القانونيت والإقتصاديت . ب 


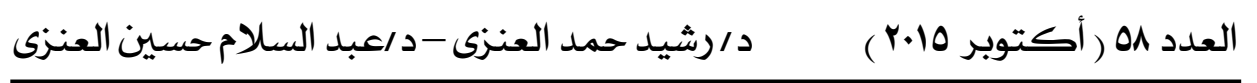

لقد حـاول هذا البحث الإجابـة عن عدة أسـلة مهمـة تمحورت حول تعريـف المقاومة المسلحة ومشروعيتها ـ كما أن هذا البحث أوضح أن القانون الدولي الإنساني انطوى على نظرة تتسم بالحداثة والتيسير إزاء أفراد المقاومـة ، مـن خـلال إقرار

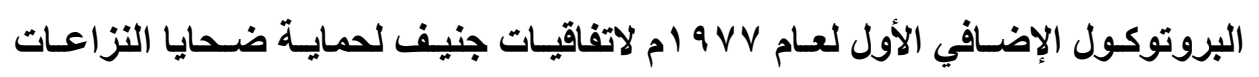

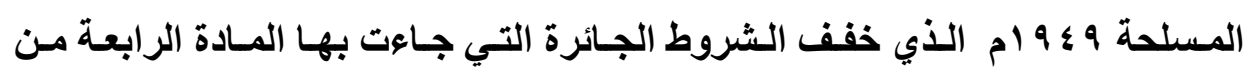

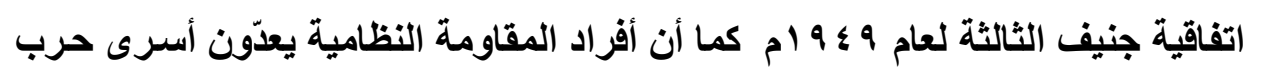
إذا مـا وقعسوا في قبـة الخصم ، فتطلب مسن المقـاتلين أعضاء جماعـات المقاومسة المسلحة أن يميزوا أنفسهم عن السكان المدنيين في أثناء اشتباكهم في هجوم أو في عملية عسكرية تجهز للهجوم ، ولا شك أنّ ذلك يعدّ تطوراً محموداً لمصلحة المقاومسة

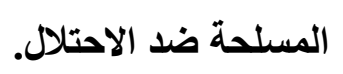

خلاصـة القـول إنّ المقاومـة المسـلحة أصسبحت مـن قواعــ القـانون الــولي العرفـي باعتبارها أداة الثعوب المستضعفة للتخلص من الاحتلا الجائر لأراضيها ومقدراتها ، ولا يقلّل

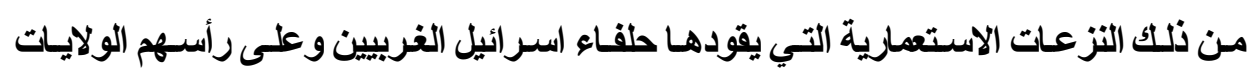
المتحدة لضرب المقاومة المشروعة للشعب القلسطيني وحقه في تقرير مصيرهو تكوين دولته على أرضه.

"انتهى بحمد الله"

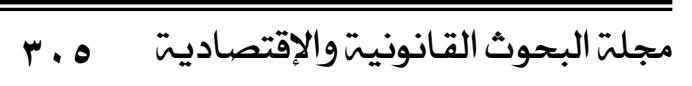


العدد 01 ( أكتوبر 10.r. ) د/رشيد حمد العنزى - م/عبد السلام حسين العنزى

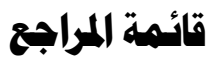

\section{أولا: الاغة العربية}

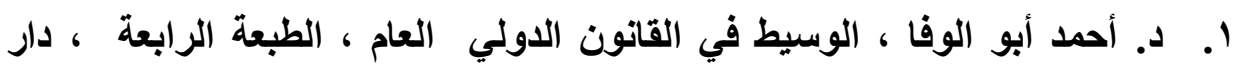

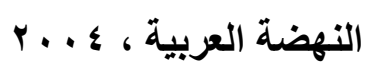

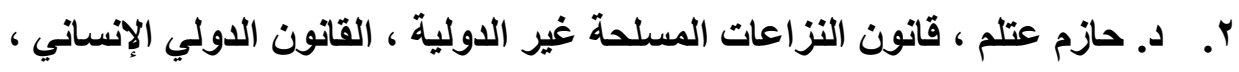

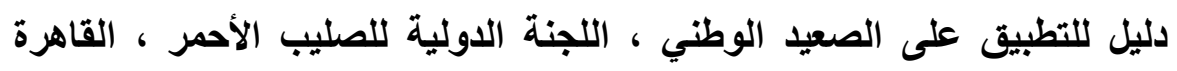

r... T

r. د. حامد سلطان و د. عائشة راتب و د. صلاح الدين عامر ، القانون الدولي العام ،

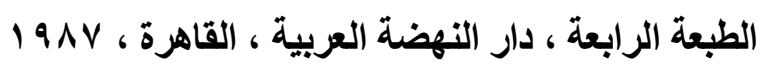

؛. د. رشاد عارف السيد ، المسؤولية الدولية عن أضرار الحروب العربية

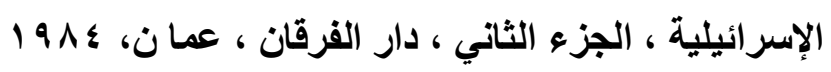

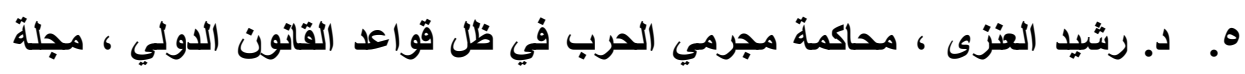

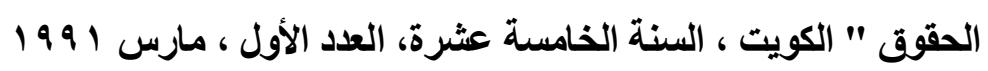

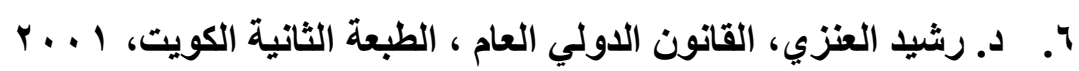

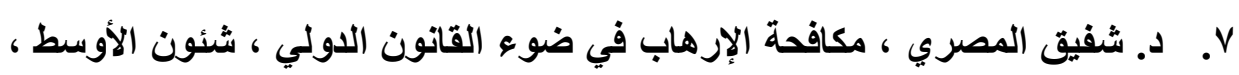

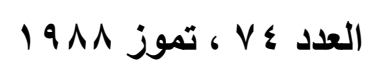

^. د. صلاح الدين عامر ، المقاومة الثعبية المسلحة ، دار الفكر العربي ، دون سنة

نشر

9. . د. عبد العزيز مخيمر ، الإرهاب الاولي ، القاهرة 9194

مجلت البحوث القانونيت والإقتصاديت 


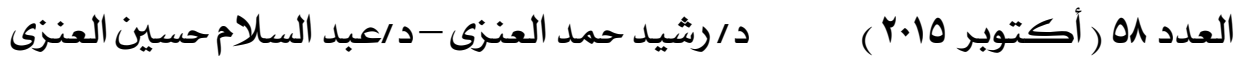

• ـ د. عز الدين فودة ، الاحتلال الإسرائيلي والمقاومة القلسطينية في ضوء القانون

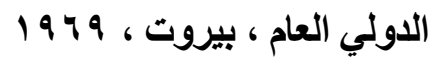

11. د. عيسى العنزي و د. ندى الدعيج ، دراسة لحقوق الإنسان في وقتي السلم

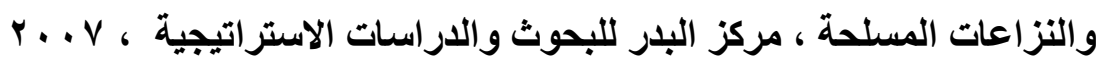

Y ا. د. كمال حماد، الإرهاب والمقاومة في ضوء القانون الدولي العام ، بيروت $r \ldots r$

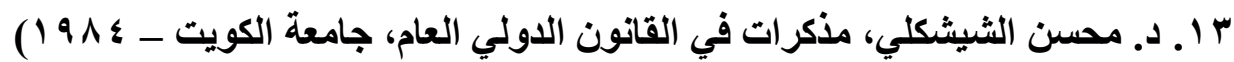
ـ ا ـ د. محمد محي الدين ، مكافحة الإرهاب في الوطني العربي ، الرياض، 999 19 ه ـ د. محمد يوسف علوان ، القانون الدولي العام ، وثائق ومعاهدات دولية ، عمان ، $19 \vee \wedge$

ثانيا: الاغة الفرنسية

1. Bedjaoui Mohamed, la revolution algerienne et le driot, Edition del'association internationale des juristes Democrates ، 1961.

2. C.Schmidt, sur quelques questions de succession possees par

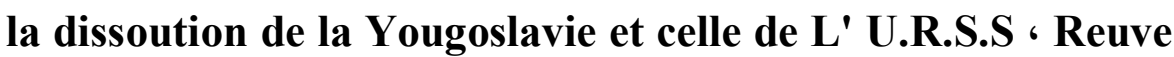
Generale de Droit international public ، 1992.

3. Draper, G.I.A, "The Legal classification of belligerents individuals Humanitarian Law and armed conflicts), Centre de Droit International de l"University de Bruxelles Institute de Socioligie, 1971. 


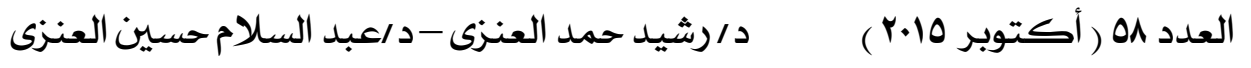

4. Fauchille, Paul, Traite de droit International Public, Tome II, Guerre et Neutralite, Paris, 1921

5. Ford, W.J,Les Members des mouvements de resistance internationale, Extrait de la revue international de le croixrouge, geneve, octobre, nouvembre, Decembre 1967- janvier 1968,pp. 28.

6. Meyrowitz Henri, la Guerilla et le droit de la guerre, problemes principaux, revue Belge de droit international, 1971

7. Patrick Dailler, Alain Pettet, Droit Internationl Public, 7 edition , L.D.G,I

8. Pinto Roger, les Regles du Droits International concernert la Guerre Civil, Recueil des cours de l'Academie de Droit interntional de la Haye, 1956-1,tome114

9. Scelle Georges, la conference de Bruxelles de 1874, librairie de la societe de Recueit. J.B.sirey et du journal du palais, paris, 1906

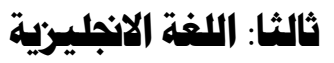

1. Brownlie, Ian., Principles of Public International Law, 3 ed 1979

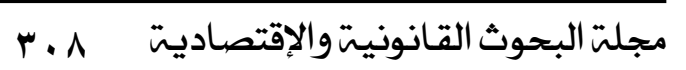




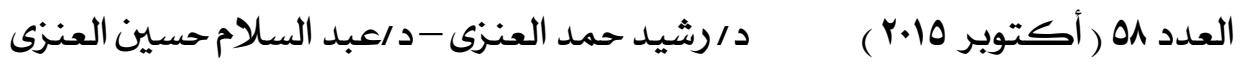

2. Draper, G.I.A, The Geneva Conventions of 1949, Recueil des cours de I' Academie de Droit International de la Haye, 1965.

3. Espiell, Hector Gros, the Right to Self- Determination : Implementation of United Nations Resolutions - Study Prepared by Hector Gros Espiell, Special Rapporteur of the Sub-Commission on Prevention of Discrimination of Minorities . New York : U.N. Doc E/CN 4/sub. 2/405 rev. 1, UN . sales no. E79-x1 v.5 (1980).

4. Gradam, J.G., "Noncombatant Immunity and the Gulf Conflict", Virginia Journal of International Law, vol. 32, 1992

5. Hudson, Manley O., (editor), International Legislation, vol. 7, 1941

6. Kunz, Josef, L., "The Geneva Conventions of August 12, 1949, In (Law and Politics in the world community).

7. O'Connell, D.P., The Law of State Succession, Cambridge University Press, 1956, p. 425.

8. Oppenheim, L., International Law, vol. II, war and neutrality, $7^{\text {th }}$ ed., Lauterpacht, (ed.), London, 1958

9. Karen Parker and Lyn Neylon, Jus Cogens: Compelling the

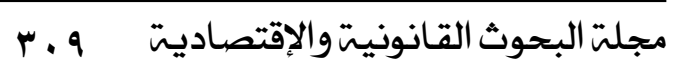




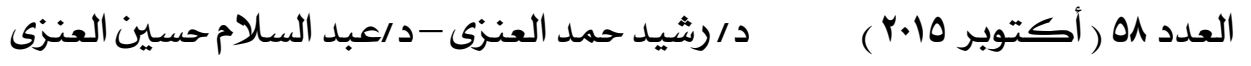

Law of Human Rights, Hastings International and Comparative law Review, vol. 12, (1989)

10. Roberts, A ,Civil Resistance as a Technique in International Relations, the Yearbook of World Affairs, 1970

11. Roberts, A. and Guelff, R., (eds.), Documents on the Laws of War, 2nd ed., Oxford, (1989),

12. Shaw, International Law, $2^{\text {nd }}$. ed. Cambridge, (1986)

13. Sofaer, Abraham D., "The U.S. Decision not to Ratify Protocol 1 to the Geneva Conventions on the Protection of War Victims The Rationale for the United States Decision", A.J.I.L, vol. 82, 1988

14. von Schorlemer, Sabine, Human Rights: Substantive and International Implications of the War Against Terrorism, EJIL, vol. 14, 2003

15. Young, Reuven, Defining Terrorism: The Evolution of Terrorism as a Legal Concept in International Law and its Influence on Definitions in Domestic Legislation, Boston College International and Comparative Law Review, vol. 29, 2006

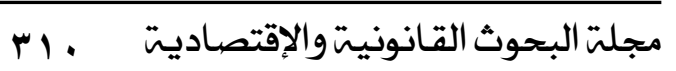




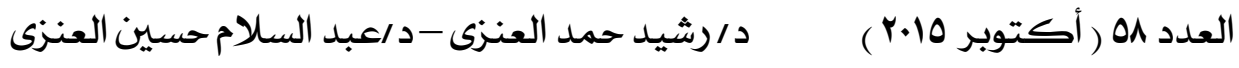

\section{رابعا: أحكام همكمة العدل الدولية}

16. Barcelona Traction, Light and Power Company Limited (Belgium v. Spain), ICJ Reports 1970

17. Case Concerning East Timor (Portugal v. Australia), ICJ Reports 1995

18. Legality of the threat of Use of Nuclear Weapons, advisory opinion, ICJ Reports, 1996

19. Military and Paramilitary Activities in and against Nicaragua (Nicaragua v. United States of America), Merits, ICJ Reports 1986

20. South West Africa in Namibia, (Advisory opinion), I.C.J Reports, 1971.

21. Western Sahara Case, Advisory opinion, I.C.J Reports, 1975

\section{خاهسا: وثائق وتقارير}

22. Actes de la-conference de Bruxelles, 1874, Bruxelles imfremerie du monitor Belge, 1874.

23. Final Communiqué of the Ninth Extraordinary Session of the Islamic Conference of Foreign Ministers, Qatar, 10 October 2001, para. 6 citied in Foreign Policy January/February 2002.

مجلتّ البحوث القانونيت والإقتصاديت 1 11 


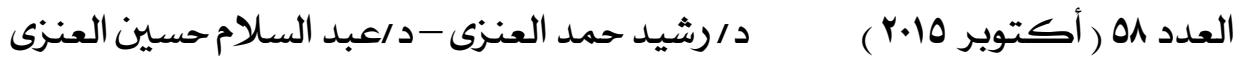

24. General Assembly Resolution No.A/ ReS /60/251,8 of May 2006.

25. Report of Ad Hoc Committee Established by General Assembly Resolution 52/210 of 17 December 1996, Sixth Session 28 January - 1 February 2002), GAOR, FiftySeventh Session, Supplement No. 37 A/57/37), Annex IV, Texts Related to Article 18 of the draft Comprehensive Convention, :Text Proposed by the Member States of the Organization of the Islamic Conference'. 